\title{
The role of mycobacteria in Crohn's disease
}

\author{
DAPHNE E. THOMPSON \\ Department of Health, Skipton House, 80 London Road, London SE1 6LW \\ This review is based upon a report prepared for the Advisory Committee on Dangerous Pathogens, a Joint \\ Committee of the Department of Health and the Health and Safety Executive.
}

\section{Introduction}

Crohn's disease (CD) was first described in 1932 as a chronic inflammation of the terminal ileum. CD affects primarily young adults and the elderly, but can occur at any age. ${ }^{1}$ It is now recognised that although involvement of the ileocaecal area is most frequent $(50 \%)$, the disease can effect any area of the gastrointestinal tract from mouth to anus, ${ }^{1}$ including the nasal cavity. ${ }^{2}$ In children and adolescents there is often upper gastrointestinal tract involvement. ${ }^{3}$ Symptoms include fever, diarrhoea, cramping pain in the abdomen, nausea, vomiting, anaemia and weight loss. ${ }^{1}$ During the past 30 years, several rare complications of $\mathrm{CD}$ have been described that can be life threatening. ${ }^{4}$

$\mathrm{CD}$ is one of a group of inflammatory bowel diseases (IBD) that also includes ulcerative colitis (UC). The clinical signs of $\mathrm{CD}$ and $\mathrm{UC}$ are similar; consequently mis-diagnosis occurs in an estimated $20 \%$ of cases. ${ }^{1}$ UC affects primarily the mucosa which is congested with diffuse mononuclear cell infiltration of the lamina propria. There is also marked goblet cell depletion and gland infiltration by neutrophils. In contrast, both gland and goblet cells are preserved in CD. It is a granulomatous disease affecting the submucosa which is characterised by infiltration of inflammatory cells. $\mathrm{CD}$ is an invasive disease of the bowel wall, thus sampling by biopsy may be ineffective and can impede diagnosis. ${ }^{5}$

Understanding of the epidemiology of $\mathrm{CD}$ is confused because many of the symptoms of the disease are shared by other IBD. There is a lack of uniformity in the criteria used and the emphasis they are given in aetiological investigations. Population studies have indicated that $\mathrm{CD}$ is more frequent in the developed than in the developing world, where it is seldom reported. ${ }^{6}$ It is prevalent particularly in Scandinavia, the USA and the UK and also in Jewish populations. ${ }^{7,8}$

Received 20 April 1993; revised version received 25 Feb. 1994; accepted 7 March 1994

Present address for correspondence: DTI Biotechnology Unit, Laboratory of the Government Chemist, Queen's Road, Teddington, Middlesex, TW11 0LY.
Population studies of different ethnic groups, migrants and families have been used to investigate whether environmental, dietary or genetic links are implicated in the aetiology of $\mathrm{CD} .{ }^{9}$ Although some studies suggest a hereditary predisposition, ${ }^{10} \mathrm{CD}$ is thought to have a multifactorial aetiology involving genetic, environmental, microbial and immunological factors.

A specific aetiological agent of $C D$ has not been identified. The inflammatory nature of the disease has led to studies focusing on imbalance of the immune system, resulting from either an inherited disorder or as a response to microbial antigens in the gut. A wide variety of gastrointestinal conditions, such as enterocolonic infections, can mimic $\mathrm{CD}$ and so confuse these investigations. ${ }^{5}$ Researchers testing the microbial hypothesis have sought evidence from culture, immunology, chemotherapy and animal models. The specificity and sensitivity of bacterial detection has improved recently with the application of molecular biological techniques. Despite considerable effort, progress in understanding $\mathrm{CD}$ has been slow. The results generated often have been inconclusive and do not clearly indicate whether the agent under investigation is causal or consequential.

Other diseases in man, animals and birds have symptoms similar to $\mathrm{CD}$. They include various tuberculous-type diseases associated with the genus Mycobacterium. Mycobacteria can be divided crudely into specific and opportunist pathogens. The latter are free-living saprophytes commonly found in the environment ${ }^{11}$ and include the $M$. avium-intracellulare group, referred to as the MAI complex. They have been associated with opportunist infections in AIDS patients, ${ }^{12,13}$ including a terminal ileitis which resembles CD clinically. ${ }^{14}$

Studies based on phenotype ${ }^{15}$ and genotype ${ }^{16-20}$ have shown that $M$. paratuberculosis clusters with the MAI complex. This species colonises the intestinal mucosa of ruminants causing Johne's disease (JD). ${ }^{21}$ $\mathrm{CD}$ and JD share clinical symptoms. Both are chronic granulomatous diseases of the gut affecting nutrient absorption and frequently affecting the young. Consequently, it has been proposed that M. paratuberculosis 
is the causative agent of $\mathrm{CD} \cdot{ }^{6,22}$ Interpretation of results from studies on this group of organisms is compounded by several factors. Compared to other organisms in faecal samples they are present in low numbers. ${ }^{6,23} \mathrm{~A}$ decontamination procedure is required to eliminate most other organisms present in faecal samples. In practice, the decontamination protocol differs between laboratories ${ }^{11}$ and the regimen adopted can bias the isolation of mycobacterial species. ${ }^{24}$ Because of the ubiquity of these organisms, care has to be taken to guarantee that the bacteria represent true isolates from a sample and not environmental contaminants. ${ }^{6}$ The purpose of this review is to evaluate the evidence linking $M$. paratuberculosis to $\mathrm{CD}$.

\section{Epidemiology of Crohn's disease}

\section{Population studies}

CD occurs most frequently in the USA, UK and Scandinavia. ${ }^{25,26}$ It is less frequent in Central Europe and rarely reported in Asia, Africa and South America. ${ }^{27,28}$ Conversely, where $\mathrm{CD}$ is rare, other mycobacterial diseases, such as tuberculosis and leprosy, are common. ${ }^{1} \mathrm{An}$ increased incidence of $\mathrm{CD}$ was reported during the 1960s in areas where it was prevalent. ${ }^{29,30}$ During the 1970 s there was a tendency towards a plateau in these regions. ${ }^{29,31,32}$ Recent data from specific locations within these areas suggest that the incidence may be falling. ${ }^{33,34}$ In the USA, the decrease in tuberculosis in the black population was accompanied by a corresponding increase in $\mathrm{CD}^{35}$ Currently, the incidence of CD is declining in the USA and the incidence of tuberculosis is again increasing. ${ }^{36}$

Population studies show that equal numbers of males and females are affected by $C D .{ }^{37}$ Peak ages for $\mathrm{CD}$ are $15-25$ years and $50-80$ years. $^{32}$ There is no clear delineation of risk between urban and rural dwellers, ${ }^{32}$ but there have been reports of a higher prevalence in urban areas in Alaska ${ }^{38}$ and also in Ashkenazi Jews, in whom the incidence appeared to rise with migration to an urban population. ${ }^{39}$ Epidemiology of CD has been studied in selected cases from small groups rather than large populations; consequently it is a difficult and muddled area ${ }^{26}$

Studies of Jewish populations provide evidence for both genetic and environmental factors in the aetiology of $C D$. Genetic factors are implied from the seven-fold increase of CD among Jews ${ }^{40-42}$ compared to the non-Jewish population living in the same locality. ${ }^{43}$ There has been an increased incidence of $\mathrm{CD}$ in the Jewish populations of Tel Aviv and Beer Sheva over the past 20 years. ${ }^{44}$ In contrast, CD is rare among Bedouin Arabs living in Beer Sheva. ${ }^{45}$ The incidence of $\mathrm{CD}$ in these Bedouin Arabs, a rural population, has not increased in recent years and is similar to that of urban populations of Arabs in Kuwait and Egypt. ${ }^{27}$ Arabs with chronic intestinal disease are more likely to have tuberculosis than $\mathrm{CD}{ }^{46}$ The incidence of $C D$ among Jews in Beer Sheva varied with their origin, i.e., Israeli versus USA- or Europeanborn. ${ }^{47}$ This trend has emerged from several studies of subgroups living in, or originating from, different geographic locations. The disease is less common in non-Ashkenazi, Israeli-born Jews, than in Ashkenazi Jews, although the incidence in first degree relatives of cases was similar in Ashkenazi and non-Ashkenazi Jews. $^{48}$

It was proposed that the increased incidence of $C D$ in Ashkenazi Jews, who eat more meat, milk and eggs, may be linked to diet but investigations showed that the prevalence of $\mathrm{CD}$ cannot be explained by diet alone, as the incidence in this group is lower in Tel Aviv than in the USA ${ }^{49}$ Further studies substantiate a multifactorial aetiology for $\mathrm{CD}$. Jewish $\mathrm{CD}$ patients in Los Angeles showed a positive family history of $27.5 \% .{ }^{42}$ In a follow-up study of Ashkenazi Jews with $\mathrm{CD}$ in California, the country of origin of the grandparents was included in the analysis. ${ }^{50} \mathrm{~A}$ parallel study was performed in Israel on Ashkenazi and American-born Jews with $\mathrm{CD} .^{51}$ Both found that a significant majority of Ashkenazi Jews originated from "middle" Europe, suggesting a genetic link. However, in a study of Jews in Baltimore, intermarriage was not associated with a greater risk of $\mathrm{CD}$, arguing against a genetic link. ${ }^{27}$ In summary, the epidemiological data for the Jewish population provides evidence for and against a hereditary predisposition and environmental factors.

\section{Familial studies}

The observations from studies of the incidence of $\mathrm{CD}$ in the Jewish population coincide with those from familial epidemiological studies, which indicate that the aetiology of $C D$ involves a polygenic inheritance with environmental influences. ${ }^{25,26,51}$ The geographic distribution of $\mathrm{CD}$ implies an environmental aetiology $y^{25}$ but the few reports of IBD in patients' spouses $^{52-55}$ and adopted children ${ }^{56}$ suggest that environmental factors may be less important than inheritance. The polygenic nature of $\mathrm{CD}$ has been challenged recently; a modelling study of epidemiological data has implicated a recessive gene in preference to polygenic inheritance. ${ }^{57}$ Until a suitable marker gene is found for $\mathrm{CD}$, this cannot be substantiated.

An increased family prevalence in $C D$ has been reported from several specialist referral centres ${ }^{10,58,59}$ and from population studies. ${ }^{55,60} \mathrm{~A}$ genetic predisposition in first degree relatives 13 times that of the control population was found in Cardiff. ${ }^{55} \mathrm{~A}$ similar study in Sweden reported a prevalence in first degree relatives of 21 times the expected level. ${ }^{6}$ Corroborative evidence for an inherited predisposition was provided in the Swedish study from monozygotic and dizygotic twins. Concordance for CD occurred in four of six pairs of monozygotic twins, but in no dizygotic twins. ${ }^{6}$ This was consonant with data from a Swedish twin register, where eight of 18 monozygotic twins were 
concordant for $\mathrm{CD}$ compared to one of 26 pairs of dizygotic twins. ${ }^{6}$

\section{Genetic linkage}

The epidemiological association of $\mathrm{CD}$ with countries, races and more than one family member ${ }^{61}$ has resulted in a quest for a genetic marker. It has been proposed that a genetic defect may prevent the patient from mounting a controlled and effective immune response to the causative agent. ${ }^{62}$ No evidence was found in familial studies, ${ }^{63}$ or in a study of Jewish patients ${ }^{64}$ for linkage with HLA type. Clinical patterns in siblings indicated that a genetic factor not linked to the HLA system may be involved. ${ }^{65}$ However, extensive analysis of all the available data for HLA has shown an increased but not constant association of HLA-2 with CD in caucasians. ${ }^{66}$ Similarly, IBD patients in the Japanese and Israeli Jewish population with restricted genetic heterogeneity have definite, but different, HLA phenotypes. ${ }^{62}$ Chromosome 14 , which regulates the immunoglobulin heavy chain complex, may be implicated in CD. There is evidence for $^{67}$ and against ${ }^{68}$ the association of certain heavy chain allotypes with $\mathrm{CD}$.

The inclusion of patients spanning different clinical conditions of $\mathrm{CD}$, i.e., mild versus chronic, and those with and without remission, may obscure direct relationships with a genetic marker. It has been proposed that, because of differing responses to therapy, a subclassification of CD is required ${ }^{69}$ Cluster analysis has indicated that $\mathrm{CD}$ patients fall into two groups - those who achieve remission within 3 years and those in whom disease persists after 3 years. $^{70}$ The immunological data for $\mathrm{CD}$ do not suggest a simple inherited disorder, but rather a multifactorial disorder. $^{62}$

\section{The role of diet in $C D$}

Food antigens have been considered as aggravating factors in $\mathrm{CD} .{ }^{71}$ There is some evidence for immunity against food antigens, ${ }^{72,73}$ but whether this is a primary or secondary response remains unclear. Specific sensitisation to cow's milk proteins has been demonstrated.$^{74}$ Corroborating this was the reported ability of $\beta$-lactoglobulin to activate both peripheral and intestinal mononuclear cells. ${ }^{75}$ However, an examination of hybridoma supernates prepared from active $B$ cells of mesenteric lymph nodes of IBD patients found no evidence for increased antibodies to milk, cabbage or wheat. ${ }^{76}$ The differing results may be a consequence of examining different immunological cell types.

An international study investigating childhood factors, including cereal consumption and frequency of breast feeding, found no significant differences between $\mathrm{CD}$ patients and controls, ${ }^{77}$ although it has been noted that $C D$ patients were over-represented among those with no or little breast feeding. ${ }^{78}$ Lack of dietary fibre ${ }^{77,79}$ and an increased refined carbohydrate consumption, ${ }^{80}$ in particular refined sugar, ${ }^{81}$ have also been postulated to play a role. The levels of volatile fatty acids in the gut are increased with the consumption of dietary fibre. Corroborating evidence for the role of dietary fibre is the report that increased volatile fatty acids may be protective in $\mathrm{CD} .^{82}$ Special diets, ${ }^{83}$ including high calorie diets, ${ }^{84}$ have been reported to cause remission in $\mathrm{CD}$. However, no clear clinical benefit emerged when two groups of $C D$ patients were given a diet containing either a high fibre-low refined carbohydrate or a low fibre-high refined carbohydrate content. ${ }^{85}$ The role of diet in CD remains speculative.

\section{Bacteria as the aetiological agents in $C D$}

The elusive aetiology of $\mathrm{CD}$ has led researchers to speculate that intestinal bacteria, both indigenous and pathogenic, may play a causal role in the disease. Comparative investigations of the gross intestinal flora between control groups and $\mathrm{CD}$ patients have been performed. Evidence for specific bacterial involvement has been sought from various microbiological and immunological techniques. However, there is little consistency with respect to the bacterial species implicated in these studies. The disparity reflects the different techniques and experimental approaches applied which obscures whether certain bacterial species play a causal or consequential role.

Microbiological investigations. A study of gross intestinal flora reported that $C D$ patients with clinically active disease had significantly more aerobes in faecal samples than patients with quiescent disease, UC or controls. The increase in aerobes did not correlate with any of the $\mathrm{CD}$ clinical indices ${ }^{86}$ indicating that the changes were non-specific. ${ }^{87}$ Microbiological and histological examination of biopsy specimens from IBD patients showed Klebsiella spp. and Chlamydia spp. in CD patients, but these organisms were not confined to CD patients and occurred in other patient groups. ${ }^{88}$ Similarly, intestinal bacteria and potential pathogens were isolated from the mesenteric lymph nodes and ileal serosa, respectively, in a higher percentage of $C D$ patients than controls. This suggests that leakage from the lumen occurs in a high proportion of CD patients. ${ }^{89}$

Immunological studies. Higher levels of agglutinins to Eubacterium and Peptostreptococcus spp., but not to Clostridium colinum, Citrobacter freundii, Campylobacter sputorum, mycobacteria and chlamydiae were found in the sera of CD patients than in the sera of controls; this was reported for two separate geographic areas-- Rotterdam ${ }^{90-92}$ and Cardiff. ${ }^{93}$ To ascertain the significance of these findings, the occurrence of agglutinins to Eubacterium and Peptostreptococcus spp. in the sera of CD patients was compared to patients in North-East India with acute or chronic diarrhoea.The study aimed to establish if the incidence of circulating agglutinin was a consequence of increased exposure to these organisms caused by tissue 
damage. Agglutinins were found less frequently in the patient groups from India with acute and chronic diarrhoea (11\% and $17 \%$ respectively) than those with $\mathrm{CD}$ from Cardiff $(44 \%)$, indicating that these organisms may play a causal role ${ }^{94}$ However, relative numbers of these organisms in the intestinal flora of the two populations was not determined; therefore, the significance of these results cannot be evaluated.

Serum antibody titres to Bacteroides fragilis, and to a lesser extent Enterococcus faecalis, were reported to correlate with the severity of disease in patients with $\mathrm{CD}$ and UC. ${ }^{95}$ These are common intestinal commensals and increased circulating antibody probably reflects exposure to these antigens and so a secondary rather than a primary response.

Quantitative investigation of serum antibodies to several enteric pathogens has not correlated with the severity of the disease. Increased antibody titres were reported for some Escherichia coli serotypes, ${ }^{96,97}$ and to Camp. jejuni, Camp. fetus, Listeria monocytogenes, Brucella abortus, Yersinia pseudotuberculosis and $Y$. enterocolitica in complement fixation tests (CFT) with commercially prepared antigens, but these results proved statistically insignificant. The presence of raised serum antibody to all seven enteric pathogens examined indicated that this was probably a consequence of polyclonal B-cell stimulation during periods of active inflammation and was non-specific. The levels of serum antibodies showed no correlation with the severity of disease. ${ }^{98} \mathrm{~A}$ study of 18 patients found no microbiological or serological evidence for the association of $Y$. enterocolitica with CD. ${ }^{99}$

Infection with several organisms produces clinical symptoms similar to $\mathrm{CD}$ and can confound its diagnosis. ${ }^{100}$ These include Actinomyces israelii, ${ }^{101}$ Salmonella spp., ${ }^{102}$ Giardia lamblia, ${ }^{103}$ Camp. jejuni/ coli ${ }^{104}$ and $Y$. enterocolitica. ${ }^{105-107}$ Chl. trachomatis causes proctitis which has been reported to be indistinguishable histologically from $\mathrm{CD} \cdot{ }^{108}$ Antibodies to Chl. trachomatis have been demonstrated more frequently in $\mathrm{CD}$ cases than controls in some studies, ${ }^{109-111}$ but not in others. ${ }^{12-114}$ Different methodology may account for these contradictory findings. An alternative approach with PCR amplification of a Chl. trachomatis plasmid was used that was capable of detecting one infected cell in $10^{4}$ cells. The study also investigated the presence of serum antibodies to $\mathrm{Chl}$. trachomatis. No evidence was found for an association between Chl. trachomatis and CD. ${ }^{115}$ The chlamydial data do not demonstrate clearly a causal or consequential role for these organisms in $\mathrm{CD}$, and the reported high levels of these organisms in some studies may be a misdiagnosis of proctitis as CD.

The epidemiological investigations of $\mathrm{CD}$ have implicated geographic areas, races and diet. The evidence is circumstantial and the contribution of any one factor to the development of $\mathrm{CD}$ remains unclear. Similarly, the role of both the indigenous flora and bacterial pathogens in the aetiology of the disease is circumstantial and serological evidence for particular organisms may be due to leakage of antigens from the lumen. The presence of pathogens can also confound the diagnosis of $\mathrm{CD}$. The role of mycobacteria in $\mathrm{CD}$ is considered later.

\section{Diseases related to $C D$ and associated with mycobacteria in man and animals}

\section{Gut disorders associated with mycobacteria in man}

In man, intestinal tuberculosis (IT) has often been confused with $\mathrm{CD}$. Although they are now considered to be distinct diseases, they share certain similarities: ${ }^{118-118}$ Person-to-person transmission of $M$. tuberculosis is rare in IT. ${ }^{119}$ Three categories of IT have been defined based on clinical symptoms ${ }^{120.121}$ that vary depending on the degree of the host's response and the organism's virulence. The ulcerative type is the most common; it is associated with intestinal infection with $M$. tuberculosis and there is pulmonary involvement. A second type, ulcerohypertrophic, can be a consequence of pulmonary or intestinal infection and results in ulcers healing with fibrosis and stenosis of the lumen. The third, the hypertrophic form, referred to as pseudotuberculosis, is rare and is caused by primary infection of the gut; it is characterised by intense fibroblastic reactions in the submucosal and serosal layers of the bowel. ${ }^{122}$

Intestinal tuberculosis must satisfy at least one of the following criteria: positive culture or the development of disease in guinea-pigs after inoculation; microscopic demonstration of acid-fast bacilli; or presence of tubercles with caseation in diseased tissue or granulomata in draining lymph nodes. The hypertrophic form seldom satisfies all of these criteria, but if one of them is met, a positive diagnosis is made. ${ }^{123}$ The diagnosis of the hypertrophic form differs in the site of the caseous necrosis; it occurs in the draining lymph nodes rather than in the intestinal tissue and culture of $M$. tuberculosis was achieved in only one-third of the cases examined. ${ }^{124,125}$ Caseous necrosis was rarely observed in the culture-positive cases. In hypertrophic IT, the inconsistency of demonstrating $M$. tuberculosis when there is caseous necrosis and vice versa questions the validity of the diagnosis and whether $\mathrm{CD}$ and hypertrophic IT should be considered distinct pathological diseases - caseous necrosis and the presence of acid-fast bacilli forming the basis for the distinction between CD and IT. ${ }^{6}$ It would be informative to establish which Mycobacterium spp. are associated with the three types of IT, and in particular whether the hypertrophic condition represents a disease caused by $M$. tuberculosis or another Mycobacterium sp., or is CD.

Only limited success has been achieved with animal models of IT with $M$. tuberculosis, suggesting that this is not the preferred site of infection with this organism. ${ }^{6}$ This contrasts with $M$. paratuberculosis infection and JD in animals, in which animal models mimicking the disease have been established. ${ }^{126}$ 


\section{Ruminants and Johne's disease}

JD is a granulomatous disease of ruminants caused by colonisation of the intestinal mucosa by $M$. paratuberculosis. Young ruminants, particularly those $<30$ days old, are susceptible to infection; ;27,128 thereafter, an age-dependent resistance develops. ${ }^{129,130}$ Clinical disease developed in sheep inoculated orally with $10^{9}$ but not $10^{3} M$. paratuberculosis organisms. ${ }^{131}$ Although the infectious dose remains unknown, investigators have inferred from morbidity that the ingestion of relatively few organisms may cause infection. ${ }^{132,133}$ A long incubation period precedes the clinical disease, ${ }^{134}$ but is probably dose related. ${ }^{58} \mathrm{JD}$ can take up to 15 years to develop, ${ }^{135}$ but occurs most frequently 3-5 years after infection with $M$. paratuberculosis. Infection of ruminants with $M$. paratuberculosis does not always result in JD. When adults become infected, the lesions are less pronounced and contain fewer bacilli, and often the organism is eliminated. ${ }^{\mathbf{1 3 6}}$ There are also reports of animals infected with $M$. paratuberculosis that never develop clinical disease, but become carriers and shed the organism throughout their lives. Susceptibility to infection varies with different cattle breeds. ${ }^{137}$ Within a chronically infected herd, animals are classified as clinically ill, subclinically infected and infected. The clinical symptoms and pathological lesions differ with ruminant species.

The immunological response in JD reflects the stage of the disease. The initial cell-mediated response is replaced with a humoral response as JD progresses. This in turn is superseded by anergy as the disease enters a chronic phase. ${ }^{138}$

$M$. paratuberculosis can be detected in JD by culture, a CFT and an enzyme-linked immunosorbent assay (ELISA). The accepted diagnosis for JD in cattle was based on the culture of $M$. paratuberculosis from faecal or tissue samples. ${ }^{139}$ The problems and length of time associated with culture of $M$. paratuberculosis have led to a search for alternative immunological techniques. Although none of these tests offers $100 \%$ reliability, $M$. paratuberculosis is detected in a high proportion of samples. For example, in a study of 26 cows with advanced JD, the CFT was positive in $81 \%$ of serum samples and $M$. paratuberculosis was isolated from $76 \%$ of faecal specimens. ${ }^{140}$ A recent PCR method based on the $16 \mathrm{~S}$ rRNA gene showed $100 \%$ correlation with culture positive samples from cattle with clinical and subclinical JD. ${ }^{141}$

A review of the available protocols noted the need for more sensitive and specific serological tests to facilitate early detection of JD in cattle. ${ }^{138}$ An ELISA based on lipoarabinomannan was described ${ }^{142}$ and evaluated in cattle. The ELISA was better at predicting faecal shedding than tissue infection but was less discriminatory $(49 \%)$ than culture $(87 \%))^{143}$ Recent improvements to this ELISA with purified antigen resulted in $100 \%$ detection in sheep ${ }^{144}$ and $83 \%$ in cattle. ${ }^{145}$ A reliable immunological method for the diagnosis of subclinically infected cattle is still needed. In asymptomatic cows, ELISA results gave 100\% specificity and $70 \%$ sensitivity. In an attempt to detect only positive results in cattle with subclinical JD, the authors chose a high ELISA antibody index thus decreasing the sensitivity. ${ }^{146}$ If $M$. paratuberculosis produces a similar disease, i.e., $C D$, in man, the diagnostic methods applied and results from immunological studies should broadly mimic those found in JD.

\section{Other animal diseases associated with mycobacteria}

Strains of atypical $M$. avium were isolated from wood-pigeons with tuberculous infection. ${ }^{147}$ Subsequently, similar strains which were distinct from $M$. avium were isolated from granulomatous lesions. ${ }^{148.149}$ The MAI complex has also been associated with granulomatous colitis in a horse. ${ }^{150} M$. paratuberculosis is grouped phylogenetically with the MAI complex. Identification of the species within this group by phenotype is difficult, especially for atypical isolates. Consequently, reports based on phenotypic identification can be unreliable. The taxonomic details of the MAI complex are considered in a later section.

Strains identified as $M$. paratuberculosis were isolated from a colony of Stumptail Macaques with clinical and pathological features resembling JD in ruminants and $M$. avium infection in primates. This was the first report of $M$. paratuberculosis infecting non-human primates. ${ }^{151}$ The criteria used to differentiate these strains from the other members of the MAI complex were based on 5S rRNA ribotyping developed by Chiodini and co-workers. ${ }^{152}$ The ribotype obtained from strains isolated in this study and strains isolated from adolescent $\mathrm{CD}$ patients gave identical profiles. ${ }^{132,133,152}$

\section{Presence of mycobacteria in food}

Although members of the MAI complex are ubiquitous in the environment, a comprehensive epidemiological study in Germany found no evidence to suggest that the environment provided the reservoir for human disease. ${ }^{153}$ This is consistent with previous reports in which soil and human isolates had different biochemical profiles. Unless the biochemical profiles change in the human gut, it seems unlikely that environmental strains provide the source for human infection. $^{24,154}$ However, if $M$. paratuberculosis or organisms of the MAI complex cause $\mathrm{CD}$, food is a likely vehicle for transmission.

Raw milk has been considered a source of mycobacterial infection. ${ }^{155}$ Strains of the MAI complex have been isolated in the USA from raw and pasteurised milk, ${ }^{156}$ and from raw milk, but not pasteurised milk in the $\mathrm{USA}^{157}$ and Australia. ${ }^{158} M$. paratuberculosis was found in the milk of nine of 26 cows 
with advanced clinical symptoms of JD. ${ }^{140}$ This is consonant with reports of $M$. leprae in the milk of mothers with leprosy. ${ }^{159}$ A study of asymptomatic cows showed a direct relationship between numbers of $M$. paratuberculosis in supramammary lymph nodes and milk, and faecal shedding. The frequency of $M$. paratuberculosis was less than occurred in symptomatic cows. ${ }^{160}$ Strains belonging to the MAI complex have been found in oysters, ${ }^{157}$ beef and pork. ${ }^{161,162}$ The MAI complex have been shown to be more heat resistant than $M$. bovis in meat products $;{ }^{163}$ naturallyoccurring isolates are reputedly more susceptible to heat than laboratory strains. ${ }^{164}$ In countries where $M$. avium infection in chickens is frequent and laying hens are kept longer, there is a corresponding increase of this group of organisms in human infections. ${ }^{153}$ It is unlikely that cooking processes commonly used for eggs, except for hard-boiling, would destroy these organisms. ${ }^{165}$

If the aetiology of $\mathrm{CD}$ and $\mathrm{JD}$ are comparable, the ingestion of a few organisms could cause disease. ${ }^{138}$ In contrast, if the situation parallels that of IT in man, the size of inoculum causing disease would be larger as results, for example, from the ingestion of milk heavily contaminated with $M$. bovis. ${ }^{124}$ The effectiveness of pasteurisation or cooking procedures and the numbers of surviving organisms would be important if $C D$ had a food-borne mycobacterial origin. There are few studies documenting the thermoresistance of the MAI complex organisms, but it has been demonstrated that they are more heat resistant than $M$. bovis. ${ }^{164,166} \mathrm{MAI}$ complex organisms in liquid media were more thermoresistant than $M$. bovis, but virulent serovars 2 and 3 were less heat resistant than avirulent serovars. ${ }^{166}$ The results from survival studies indicate that current pasteurisation processes eliminate viable MAI complex organisms.

\section{The role for mycobacteria in CD: culture, taxonomy and molecular biological studies}

\section{Culture of mycobacteria from patients with $C D$}

Mycobacteria are a heterogeneous group of acidfast bacilli. In 1932 Crohn designated CD as a disease distinct from IT because of the absence of tubercle bacilli. ${ }^{167}$ However, interest in their role as an aetiological candidate for $\mathrm{CD}$ has continued to be investigated. The first successful culture of mycobacteria from patients with IBD was in 1952 by Van Patten. ${ }^{168}$ Seven different media containing extracts from IBD lymph nodes and normal intestine were employed; five supported the growth of $M$. paratuberculosis. A total of 1043 samples from 43 patients were cultured over 12-15 months. Colonies of acid-fast bacteria were isolated from clinical specimens of three patients, but their subculture was not accomplished and so they were never formally identified. Cultivation of mesenteric lymph nodes from 27 patients with $C D$ yielded one strain of $M$. kansasii. The presence of cell-wall- deficient acid-fast bacteria was confirmed by electronmicroscopy in 22 of the patients, but these remained non-cultivable and did not revert to forms with cell walls, preventing formal identification. Spheroplasts were also observed in six of $13 \mathrm{UC}$ and one of 11 control samples, respectively. ${ }^{169}$ The occurrence of cell-wall-deficient forms of acid-fast bacteria has been described in sarcoidosis and tuberculosis. Mycobacteriophages isolated from stool and tissue samples converted mycobacteria to a lysogenic state producing "mutants" that could not be cultured, with altered appearance, drug susceptibility and staining properties. ${ }^{170}$ There are no reports of mycobacteriophages and $\mathrm{CD}$. There have been several independent reports of the isolation of slow growing mycobacteria from resected intestinal tissue of CD patients ${ }^{132,133,152,171-173}$ and from biopsy samples. ${ }^{23,174}$ Because of the invasive nature of the disease, they have been found predominantly in resected tissue specimens rather than biopsy samples. ${ }^{5}$

Biovariants of M. paratuberculosis or a new $\mathrm{Myco}$ bacterium species were isolated from teenage $C D$ patients by Chiodini. ${ }^{132,133,152}$ These isolates-Linda, Ben and Dominic-have been used extensively in subsequent studies, becoming the prototype strains for mycobacteria associated with $\mathrm{CD}^{133}$ In a further study, mycobacteria were isolated from 16 of $26 \mathrm{CD}$ patients, but not from 26 patients with UC or other bowel disorders. Seven of 10 spheroplasts isolated from $\mathrm{CD}$ patients were identified as $M$. paratuberculosis by agglutination with specific antisera raised against strain Dominic. ${ }^{152}$ In a study of 105 patients comprising UC, CD and non-IBD controls, mycobacteria and spheroplasts were isolated from all patient groups, ${ }^{23}$ but only a single isolate of $M$. paratuberculosis, biochemically similar to strain Linda, was obtained from a UC biopsy. The authenticity of this identification was later challenged by the results of molecular typing studies. ${ }^{6}$ Slow growing mycobacteria and spheroplasts were present in the clinical specimens, but sparse growth on subculture precluded their identification. They did not appear similar to strain Linda. ${ }^{23}$ Spheroplasts were detected in only $27 \%$ of resected samples from $C D$ patients and occurred more frequently in resected tissue than in biopsies. It was concluded from these results that mycobacteria were associated with diseased tissue and that they did not exclude a mycobacterial aetiology for $\mathrm{CD} .^{23}$ With improved media for culture and spheroplast reversion, ${ }^{175}$ the same research group obtained 15,10 and 19 mycobacterial isolates from $74 \mathrm{CD}, 10 \mathrm{UC}$ and 38 non-IBD patients, respectively, and 21 spheroplasts from all three patient groups. This substantiated the conclusions of their earlier study that mycobacteria were associated with diseased tissue and that the association was not restricted to $C D$ patients. Only one isolate was biochemically similar to the $\mathrm{CD}$ $M$. paratuberculosis isolate - strain Linda. The other isolates were biochemically distinct and were not speciated. ${ }^{176}$ 
Mycobacteria have been isolated in other studies of IBD. Four mycobacterial strains were isolated from resected tissue of $27 \mathrm{CD}$ patients and one from 55 controls by the culture techniques used by Chiodini. Two isolates were identified by biochemical techniques as $M$. chelonei subsp. abcessus and $M$. paratuberculosis. ${ }^{177}$ In a separate study, acid-fast bacilli were isolated from 11 of $32 \mathrm{CD}$ patients, but not from 17 IBD patients (including UC, and non-specific IBD). Two of the isolates from patients with active $C D$ were identified from cultural, physiological and biochemical data as $M$. chelone $i^{173}$ The isolation of mycobacteria other than $M$. paratuberculosis supports the findings of Graham et al. and contradicts those of Chiodini; in contrast, the absence of mycobacteria in other IBD patient groups supports Chiodini's data, and contradicts Graham's data.

The studies of Chiodini and Graham and their associates are not directly comparable because the treatment of the specimens differed. Graham's group cultured homogenates of the resected tissue, whereas Chiodini's group cultured the mucosa and submucosa from the resected tissue separately. The disinfection procedures employed by the two groups also differed. The isolation of organisms of the MAI complex other than $M$. paratuberculosis from IBD, control, UC and $\mathrm{CD}$ samples by Graham and his associates has been attributed to a lack of stringency in their decontamination process. Chiodini considered that the regimen used by Graham precluded the isolation of $M$. paratuberculosis and that their mycobacterial isolates were environmental mycobacteria, which occur at similar levels. ${ }^{6}$ However, the decontamination procedure of Graham did enable the isolation of strain Linda and a similar strain. ${ }^{23}$ Other groups used the Chiodini methodology and obtained mycobacterial isolates other than $M$. paratuberculosis from CD tissue. ${ }^{174,177}$

In summary, the data on the isolation and identification of mycobacteria, and in particular $M$. paratuberculosis, from CD and IBD patients are conflicting and confusing. The disarray stems from the different techniques and stringencies applied by different groups. The problem is further exacerbated by the occurrence of spheroplasts. The role of mycobacteriophage in their formation remains to be investigated.

\section{Taxonomy of the mycobacteria implicated in $C D$}

The discrepancy over the mycobacterial species implicated in CD arises from the taxonomic methods employed. Originally, biochemical techniques were used for speciation, but this approach is unreliable, particularly for species of the MAI complex. ${ }^{178}$ Mycobactin auxotrophy is the principal criterion for ascribing isolates to the taxon $M$. paratuberculosis in preference to the MAI complex. ${ }^{179}$ There are reports of atypical animal isolates of $M$. avium that are mycobactin dependent. ${ }^{180-182}$ It has been reported recently that the demonstration of mycobactin dependence requires rigorous experimental conditions $;{ }^{179}$ these may not have been practised in earlier studies.

A more precise identification of mycobacterial isolates from CD patients was achieved by restriction fragment length polymorphism (RFLP) with probes to the 5S rRNA of E. coli. Identical restriction patterns were obtained with 11 restriction endonucleases (RE) for M. paratuberculosis ATCC19698 and three CD isolates (Dominic, Ben and Linda) and also, with spheroplast and cell-wall-producing revertants of these three strains. The RFLP patterns were distinct from those obtained with strains of the MAI complex serovars 2 and 4 and $M$. kansasii. $^{152}$

Southern hybridisation studies in which the $5 \mathrm{~S}$ rRNA probe was replaced with genomic clones of strain Ben also gave identical profiles for the $M$. paratuberculosis and CD isolates Ben, Dominic and Linda. The RFLP patterns obtained with these strains were again distinct from those obtained with strains of M. phlei, M. kansasii and the MAI complex serovars 2 and 5. One genomic clone distinguished $\mathrm{CD}$ isolates from strains of the MAI complex serovars 2 and 5. ${ }^{183}$ A second series of three clones derived from the same genetic library produced similar, but not identical RFLP patterns with three $M$. paratuberculosis strains -ATCC19698, a JD isolate and strain 18 (isolated and identified by biochemical criteria by Merkal ${ }^{184}$ ). RFLP analysis of strain 18 gave banding patterns identical to $M$. avium serovar 2. Subsequent studies have confirmed the designation of strain 18 as $M$. avium. ${ }^{185-187}$ Strain 18 has been used in several immunological studies to assess the humoral response in CD patients (see Immunology section).

The studies by Chiodini's group offered improved speciation of the CD isolates, but were limited to a few strains of $M$. paratuberculosis. Two comprehensive studies of $>100$ strains examined the genetic variation among isolates of $M$. paratuberculosis. A probe directed against a repetitive DNA sequence specific to $M$. paratuberculosis was used in the RFLP analysis. Cattle isolates of $M$. paratuberculosis from diverse origins showed remarkable RE conservation, and the patterns obtained were generally distinct from sheep and goat isolates. ${ }^{185} \mathrm{~A}$ second study confirmed the heterogeneity among isolates of $M$. paratuberculosis and included strain Linda, the CD isolate, which had a pattern identical to an Australian cattle isolate. ${ }^{188}$ In contrast, a separate study with $I S 900$, the repetitive DNA sequence specific for $M$. paratuberculosis which differentiated $M$. paratuberculosis and CD isolates from two serovars of $M$. avium, ${ }^{189}$ was unable to distinguish between ovine and bovine strains within $M$. paratuberculosis in the same RE digests. Four distinct patterns within strains of $M$. paratuberculosis were produced. ${ }^{186}$

The heterogeneity of $M$. paratuberculosis strains indicated from Southern blot analysis with insertion sequences as probes ${ }^{185,186,188}$ is corroborated by similar studies with a probe directed against the 16S rRNA; negative results were obtained with some field isolates 
of $M$. paratuberculosis. ${ }^{20}$ This was unexpected and suggests either mis-identification, or that $M$. paratuberculosis comprises of a heterogeneous clade and so questions the authenticity of defining $M$. paratuberculosis as a single species. Partial 16S rRNA sequence analysis over the most variable regions of the molecule showed that $M$. paratuberculosis was indistinguishable from $M$. intracellulare serovars $4,5,6$, $8,9,10$ and 11 and differed in one position from $M$. avium, suggesting that these should be assigned to $M$. avium. ${ }^{190}$ The close phylogenic relationship of $M$. avium and $M$. paratuberculosis is indicated by the inability of the $16 \mathrm{~S}$ rRNA probe to distinguish between some strains of $M$. avium and $M$. paratuberculosis. ${ }^{20}$ DNA homology studies suggest that $M$. paratuberculosis should be considered a subspecies of $M$. avium. ${ }^{16,17,149}$ Immunodiffusion ${ }^{191}$ and cellular fatty acid analysis ${ }^{17}$ also indicate that $M$. paratuberculosis and $M$. avium share a common line of descent and diverged recently. ${ }^{19}$

The atypical wood-pigeon isolates ${ }^{192}$ did not hybridise with the repetitive element specific for $M$. paratuberculosis, ${ }^{187}$ suggesting that they may form a clade distinct from $M$. paratuberculosis. This corroborates evidence from immunodiffusion studies of two variants of $M$. avium that the atypical wood-pigeon isolates belonged to Group A, whereas $M$. paratuberculosis, with the exception of two strains, belonged to Group B. ${ }^{191}$ It has been proposed from DNA homology studies that $M$. avium be subdivided into three subspecies, avium, paratuberculosis and columbae. ${ }^{16}$ The latter group contains the wood-pigeon strains.

The position of the taxon $M$. paratuberculosis within the MAI complex requires further clarification to elucidate if there is a putative role for $M$. paratuberculosis alone, or in combination with MAI complex species, in CD and in granulomatous disease in animals. In this respect, paratuberculosis has been reported as indistinguishable from infection with M. avium. ${ }^{193}$

\section{Molecular typing of mycobacterial isolates in $C D$}

A search for mycobacterial species in CD tissue by use of molecular techniques instead of culture has produced inconclusive results. DNA sequences homologous to mycobacterial sequences from strain Linda were detected in resected tissue in 10 of 19 CD patients, two of six UC patients and one of six control non-IBD samples. Measurement of the melting point of the hybrids indicated that the related sequences detected were of mycobacterial origin, but were not identical to each other nor to strain Linda. The genetic relatedness of strain Linda to the type strain $M$. paratuberculosis ATCC19698 and $M$. avium was in good agreement with other studies. ${ }^{17,194}$ In-situ hybridisation studies revealed that most of the homologous sequences in CD patients occurred in the muscle layer, which is consistent with the pathology of CD. ${ }^{195}$ Mycobacterial
DNA was not detected in total DNA prepared from mesenteric lymph nodes of $21 \mathrm{CD}$ patients, ${ }^{196}$ or CD tissue from resected samples ${ }^{197}$ when probed with genomic clones of $M$. paratuberculosis strain Ben. The sensitivity of detection was calculated from tissue samples spiked with $M$. avium as $2 \times 10^{5}$ bacilliequivalent to $1 \mathrm{ng}$ of mycobacterial DNA in $10 \mu \mathrm{g}$ of human DNA or one mycobacterial genome/ 10 human cells. Three probes were employed in this study, permitting the detection of several mycobacterial species including $M$. paratuberculosis, $M$. avium, $M$. intracellulare, $M$. kansasii, $M$. bovis and $M$. tuberculosis if present. ${ }^{197}$ Mycobacterial DNA was still not detected when the sensitivity was increased 10 -fold by utilising $I S 900$ from $M$. paratuberculosis, estimated at more than 10 copies/genome. ${ }^{198}$

Several diseases with a mycobacterial aetiology, in which culture had proved unreliable or unsuccessful, have now been diagnosed by PCR. Probes directed against the $65-\mathrm{kDa}$ antigen proved more sensitive for $M$. tuberculosis than traditional culture in sputum samples. ${ }^{199}$ Sarcoidosis, a granulomatous disease, has been suspected of having a mycobacterial aetiology. Culture for $M$. tuberculosis has been unsuccessful, but homologous DNA was detected by $\mathrm{PCR}^{200-202}$ except in one study. ${ }^{203}$ PCR inhibition occurred with some tissue samples, but was removed by further sample purification. ${ }^{200}$ Published results from a more comprehensive study of sarcoidosis proved inconclusive; DNA homologous to $M$. tuberculosis occurred in only some cases of sarcoidosis suggesting that, if it was present in all samples, the PCR test was insufficiently sensitive. ${ }^{204}$ A PCR protocol has been developed that permits the detection of $M$. leprae in skin biopsies. ${ }^{205}$

Improved sensitivity for the MAI complex has been achieved with PCR for the detection of a mycobacterial heat shock protein, ${ }^{206-209}$ and has been used in conjunction with reverse dot hybridisation. ${ }^{210}$ PCR regimens specific for $M$. paratuberculosis ${ }^{211}$ and $M$. avium subsp. silvaticum, ${ }^{212}$ (the wood-pigeon isolates) ${ }^{149}$ have been developed. Amplification primers are directed against the insertion sequences $I S 900^{198}$ and $I S 902,{ }^{212}$ specific for $M$. paratuberculosis and $M$. avium subsp. silvaticum, respectively. (The original clone pMB22, encoding $I S 900$, hybridised to genomic DNA from $M$. avium serovars 2 and $5,{ }^{183}$ but the specificity for $M$. paratuberculosis was realised by increasing the stringency of hybridisation and targeting a 400-bp fragment.) The detection limits of the method were estimated at one $M$. paratuberculosis genome $/ 2500$ human cells. ${ }^{211}$ When the PCR method based on amplification of $I S 900$ was applied to mycobacterial cultures from CD tissue, DNA homologous to $M$. paratuberculosis was detected in six CD cultures and one control, but in no UC cultures; DNA homologous to $M$. avium subsp. silvaticum was detected in two CD cultures, two UC cultures and two non-IBD cultures. $M$. paratuberculosis DNA was present in $65 \%$ of CD, $4.3 \%$ of UC and $12.5 \%$ of non-IBD tissue examined. However, its presence was $10^{5}$ - and $10^{7}$-fold lower than 
in JD and the intensity of the PCR signals bore no relation to visible spheroplastic or bacillary mycobacterial growth. ${ }^{213}$

The application of PCR to CD tissue failed to detect DNA homologous to a $65-\mathrm{kDa}$ antigen from $M$. tuberculosis, $M$. kansasii, $M$. avium or $M$. paratuberculosis. The sensitivity of detection was estimated at 30 mycobacterial genomes, equivalent to one bacteria in 670 human cells. Sample inhibition, which interfered with the ability to detect mycobacteria in sarcoidosis, ${ }^{200}$ may explain why mycobacteria were not detected in CD tissue. ${ }^{214}$ Although $M$. tuberculosis was detected in similar samples, the specificity and sensitivity for other mycobacterial species may not be comparable. The inclusion of $\mathrm{CD}$ tissue spiked with $M$. paratuberculosis DNA would resolve whether tissue inhibition of PCR reaction is occurring. This approach was used to avoid false negative results; DNA homologous to $M$. paratuberculosis IS 900 was detected in six of 28 cultures from CD patients. ${ }^{215}$

Culture studies failed to resolve whether $M$. paratuberculosis or MAI complex organisms are present in $\mathrm{CD}$ or groups of $\mathrm{CD}$ patients. Unlike other mycobacterioses, except for tuberculoid leprosy and tuberculosis, culture of these organisms from clinical samples is inconsistent. Several important questions remain outstanding with respect to this hypothesis. Firstly, if $\mathrm{CD}$ is the equivalent human disease to JD and $M$. paratuberculosis is the causative organism, why are large numbers of bacilli not shed during chronic disease enabling consistent detection of $M$. paratuberculosis from a group or subgroup of CD patients? Secondly, with sensitive PCR techniques, why is $M$. paratuberculosis detected only in some CD tissue? Is the inability to demonstrate $M$. paratuberculosis because it is present at such low levels, and could the mycobacteriophage be responsible for this by transforming them into unrecognisable forms resistant to detection? Could such an event explain why the pathogenesis of $M$. paratuberculosis is different in CD from JD? Alternatively, does CD represent a group of diseases in which $M$. paratuberculosis or the MAI complex are the causative agents in some groups? The resolution of this hypothesis requires that taxonomic groupings within the MAI complex, in particular the genealogical heterogeneity within $M$. paratuberculosis, are clarified; and that very specific probes capable of differentiating between these taxa are employed to establish which organism either alone or in combination cause CD. Finally, CD patients should be grouped by age and other available criteria in analysing results.

\section{The role of mycobacteria in CD: immunological data}

\section{Detection of specific antibodies for $C D$}

In severely inflamed areas IgG-producing B cells are found in the mucosal inflammatory filtrate. ${ }^{62}$ Although a correlation has been demonstrated between both mycobacterial culture and serum antibody titre in $\mathrm{JD},{ }^{146}$ this has not been demonstrated for CD. There are conflicting reports of elevated mycobacterial antibodies in serum; the controversy has been exacerbated by the absence of specific $M$. paratuberculosis antibody or antigen.

Antibody responses to $M$. kansasii were higher in $\mathrm{CD}$ patients than in controls, but were not increased for 16 other mycobacterial species. ${ }^{169}$ Similar findings were also reported elsewhere ${ }^{216}$ but $M$. paratuberculosis was not included in either of these studies. Data suggesting increased serological response to $M$. paratuberculosis in $\mathrm{CD}$ patients was reported by collaborators of Chiodini, ${ }^{217}$ but these results have not been repeated and $M$. paratuberculosis strain 18-now reclassified as $M$. avium serovar 2-was used. Increased titres of $\operatorname{IgA}$ and $\operatorname{IgM}$, but not $\operatorname{IgG}$, to soluble antigens of $M$. tuberculosis were observed in CD patients. ${ }^{218}$ Later studies failed to demonstrate greater seroreactivity to mycobacterial antigens in $\mathrm{CD}$ patients than in controls. ${ }^{219-221}$ Agglutination studies with $M$. paratuberculosis and $M$. avium proved inconclusive with sera from equal numbers of $\mathrm{CD}$ patients and controls. ${ }^{93}$ Agglutination of mycobacterial isolates obtained from $C D$ material was demonstrated only partially with antisera prepared to the CD isolate, strain Dominic. ${ }^{152}$ There are several possible explanations for the conflicting results. The choice of microbial constituent against which the antibody is directed is important for sensitivity and specificity. Cross-reaction between immunogens of mycobacteria has been reported ${ }^{222-224}$ and between mycobacterial antigens and monoclonal antibodies prepared to various micro-organisms and to host tissue. $^{225}$

In early studies, serum antibody responses in CD patients were measured with crude mycobacterial sonicates and were often directed against cell-wall components common to mycobacteria, e.g., lipoarabinomannan. ${ }^{226}$ The significance of the antibody responses detected in these studies is difficult to assess. Firstly, antibodies to mycobacterial sonicates may be high in human serum because of the environmental ubiquity of some mycobacterial species, particularly the MAI complex. ${ }^{24,153,227}$ Therefore, the detection of antibody reacting to common mycobacterial antigens is probably not specific for CD. Corroborating this is the report that the seroreactivity to arabinomannan bore no relationship to the duration of illness and was the same for $\mathrm{CD}$ patients as for controls. ${ }^{98} \mathrm{~A}$ further criticism of the early serological studies on mycobacteria and $C D$ is that testing for cell-wall antigens may be inappropriate. Spheroplasts, observed in CD tissue, are bacterial cells which have lost their cell wall. Therefore, circulating antibody to cell-wall components may not be present.

Serological studies were performed with the cellmembrane glycolipid specific for $M$. paratuberculosis as antigen ${ }^{228}$ and the presence of mycobacterial anti- 
body was measured with an ELISA in which antigens were prepared from crude cell sonicates or purified glycolipid of $M$. paratuberculosis strain 18 . No significant differences in antibody titres were observed between $C D$ and control groups. ${ }^{229}$ The suitability of the choice of antigen was questioned because it has not been detected in animals naturally infected with $M$. paratuberculosis ${ }^{6}$, nor was it expressed in all clinical isolates of $M$. paratuberculosis. ${ }^{228}$ The antigen prepared to the glycolipid also cross-reacted with MAI serovar $2 .^{230}$ Two further studies have been conducted with a protoplasmic antigen from $M$. paratuberculosis strain 18. This preparation comprised a mixture of polypeptides. Although there was a wide variation in titre of antibody in $\mathrm{CD}$ patients to a commercial preparation of strain 18 antigen in an ELISA test, the results were not significantly different from those obtained with UC patients and controls. Immunoblotting demonstrated a strong reaction to a $45-\mathrm{kDa}$ antigen in the commercial preparation in four of 10 and a weak reaction in two of $10 \mathrm{CD}$ patients, but also occurred in four of $15 \mathrm{UC}$ patients. ${ }^{231} \mathrm{~A}$ negative correlation was also obtained between the same commercial antigen preparation and serum from 108 CD patients. ${ }^{223}$ Subsequent taxonomic studies based on genotype have designated $M$. paratuberculosis strain 18 as $M$. avium serovar 2 . These studies were not evaluating the humoral response to $M$. paratuberculosis in $\mathrm{CD}$.

Antigen A60, a membrane glycoprotein, was prepared from strains of $M$. paratuberculosis, $M$. bovis and $M$. avium. Sera from patients with tuberculosis gave a strong reaction to A60 preparations from $M$. avium and $M$. bovis in an ELISA, but were not tested against A60 preparations from M. paratuberculosis. In contrast to the results from the tuberculosis patients, sera from controls and $C D$ patients did not react with any of the $\mathrm{A} 60$ preparations. This particular antigen is expressed at high levels during the exponential growth phase in M. bovis. Because of the slow growth of MAI complex organisms, the choice of antigen may have been inappropriate. ${ }^{232}$ In a carefully conceived study, neither antigenic preparations of lipoarabinomannan, characteristic of mycobacterial spheroplasts, nor protoplasm antigens specific for the $\mathrm{CD}$ isolate strain Linda, detected significantly higher antibody titres for IgA, IgG or IgM in any subsets of CD patients compared to controls. The subsets analysed included age, sex, $C D$ activity index, location of $C D$ and duration of disease. ${ }^{233}$

Mycobacterial stress proteins are targets for the immune system in tuberculosis and leprosy and may play a role in auto-immunity. The occurrence of antibodies to ATP-binding stress proteins from the $\mathrm{CD}$ isolate strain Linda and from human material in the sera of $C D$ patients was investigated. There was no significant difference in pattern or frequency of antibodies against any single protein or combinations of proteins, making it unlikely that these mycobacterial stress proteins were implicated in the pathogenesis of
CD. ${ }^{234}$ Cell extracts from human cell lines failed to detect auto-antibodies in $\mathrm{CD}$ patients. ${ }^{235}$ Specific antibodies secreted by hybridomas were generated from activated B cells of mesenteric lymph nodes of nine patients with IBD. The hybridoma supernates seldom bound to food antigens, but bound to one or more bacterial genus, most frequently to mycobacteria including $\mathrm{CD}$ isolates. Mycobacteria are not considered normal gut flora; therefore, this result was unexpected and supports a mycobacterial role in IBD. ${ }^{76}$

Serological studies implicating agents other than mycobacteria in $\mathrm{CD}$ have been reported. Increased antibody titres have been reported for colonic mucosal extracts, ${ }^{236}$ but a subsequent study of different patient groups showed that the increased titres of antibody to colonic tissue were not specific for $\mathrm{CD}^{2}{ }^{237}$ Increased levels of complement-dependent lymphocytotoxic antibody have been reported for CD patients. ${ }^{238} \mathrm{High}$ levels of antibody to pancreatic juice (PAB) occurred in $31 \%$ of $222 \mathrm{CD}$ patients. Although the positive sera could not be correlated with subgroups of $C D, P A B$ was shown to be highly specific for $C D$ when tested against sera of patients with various chronic inflammatory disorders including UC. It was proteinaceous, stable and belonged to the IgG class. This is consonant with the reports of increased production of IgGcontaining cells ${ }^{239}$ and supports data suggesting that pancreatitis may be an extra-intestinal manifestation of CD. ${ }^{240,241}$

Antigen detection. In immunohistochemical examination of $\mathrm{CD}$ tissue, antibodies prepared to $M$. paratuberculosis, M. tuberculosis and lipoarabinomannan detected various species including $M$. tuberculosis, $M$. kansasii, $M$. fortuitum, $M$. chelonei, $M$. paratuberculosis and both spheroplast and cell wall forms of the MAI complex. Mycobacterial antigens were not detected in 67 specimens from $30 \mathrm{CD}$ patients examined, but sparsely distributed cells of $M$. tuberculosis and $M$. kansasii were detected in clinical samples. ${ }^{242}$ Of four monoclonal antibodies (MAbs) raised to $M$. avium, two showed a positive reaction with a $\mathrm{CD}$ mycobacterial isolate. The MAbs reacted with the gut wall of $C D$ patients and controls, but the location of the reaction differed in the two groups. In samples from $C D$ patients, binding occurred in the submucosa and subserosa, whereas in control groups it was limited to the lamina propria. ${ }^{243}$ These results are consistent with the clinical description of $\mathrm{CD}$ and provide circumstantial evidence for mycobacterial involvement with $\mathrm{CD}$.

Despite enhancing the specificity of the antigens and linking data to subgroups in $\mathrm{CD}$, the serological data generated do not support a mycobacterial aetiology for $\mathrm{CD}$. The situation is compounded by the absence of a specific antibody for $M$. paratuberculosis that distinguishes it from closely related mycobacteria that may be environmental contaminants. Ironically, in the only study in which increased sero-reactivity to $M$. paratuberculosis was reported, a strain of $M$. avium 
was used for the antigen preparation. ${ }^{217}$ The humoral response in $\mathrm{CD}$ is not demonstrated readily and parallels that of localised granulomatous diseases, e.g., sarcoidosis and tuberculoid leprosy. ${ }^{204}$ In JD, the mycobacterial disease that most closely resembles CD, antibody to $M$. paratuberculosis can be detected in the advanced stage of the disease, but not always in subclinical disease. Antibodies to $M$. paratuberculosis were detected in the sera of $84 \%$ of Stumptail Macaques with disease that both clinically and pathologically resembled paratuberculosis in ruminants. ${ }^{151}$ Serum antibodies may not always provide a reliable indication of mycobacterial disease. In CD this may reflect an impairment of secondary immune response which has been reported with some antigens. ${ }^{244}$

\section{Evidence for cell-mediated immunity}

In supporting a mycobacterial origin for $\mathrm{CD}$, it has been suggested that because of the chronic nature of $\mathrm{CD}$, a correlation between antibody titres and development of the disease is not always demonstrable, as in the case of tuberculoid leprosy and tuberculoidtype paratuberculosis in cattle, ${ }^{6}$ and that the most useful immunological data are from assays based on cell-mediated immunity (CMI) or delayed-type hypersensitivity (DTH). The immune response in mycobacterial infection is primarily CMI and there are increased numbers of $T$ cells in $C D$, particularly associated with granulomas in the submucosa. ${ }^{62}$

An increased proportion of positive skin tests with standard purified protein derivatives (PPD) or bacterial antigens derived from atypical mycobacteria belonging to Runyon Groups I, II or III were not observed in CD patients. ${ }^{245,246}$ Similar results were obtained with PPD in a later study, ${ }^{247}$ which also failed to find evidence for the high incidence of anergy reported in CD patients. ${ }^{248}$ Positive skin tests with $M$. kansasii preparation were reported for CD samples, ${ }^{\mathbf{1 6 9}}$ but in a later study the same group found no significant difference between CD patients and controls. ${ }^{219}$

Sonicates of $M$. paratuberculosis had an inhibitory effect in a lymphocyte proliferation assay in five of six CD patients but not in other IBD patients. ${ }^{249}$ In contrast, no significant difference was observed between CD, UC and control subjects in $\mathrm{T}$ cell responses with peripheral blood lymphocytes (PBL) in a macrophage migration assay with sonicates of $M$. tuberculosis, $M$. avium, $M$. kansasii and $M$. paratuberculosis. ${ }^{250}$

$M$. leprae contains antigenic components that can either suppress or stimulate lymphocyte proliferation, depending on the form of disease, i.e., tuberculoid or lepromatous. ${ }^{251,252}$ IBD patients and controls were studied to determine if a parallel situation occurred in CD. Proliferation of PBL from normal individuals in response to $M$. paratuberculosis antigen was reduced by depletion of CD4 T cells. In CD patients, PBL proliferation was lower than that of controls in the presence of $M$. paratuberculosis antigen and the proliferative response did not increase with depletion of CD8 T cells. However, the proliferative response was reduced in the presence of other mycobacterial and candida antigens, indicating that the effect was non-specific. ${ }^{253}$ The second part of the study compared the ability of $C D$ patients and control groups to develop suppressor cell activity-measured by the ability of $M$. paratuberculosis antigen to suppress concanavalin A-induced proliferation of PBL. The ability to develop suppressor cell activity was reduced with the removal of CD8 $\mathrm{T}$ cells; suppression was observed with PBL from non-IBD groups and controls, but it was more marked in CD and UC patients, and in particular, in CD patients with active disease. It was concluded that $M$. paratuberculosis may contribute to an immunosuppressive state in CD patients. This effect was not observed with candida antigens, indicating an element of specificity; other bacterial antigens were not examined. ${ }^{253}$ As a note of caution, the mycobacterial antigen used in this study came from the laboratory ${ }^{229}$ where the antigen supposedly specific for $M$. paratuberculosis later proved to be from M. avium. ${ }^{6}$

A reduction in the levels of interleukin 2 has been reported for $C D$ patients; this was not affected by the number of CD8 cells. ${ }^{254} \mathrm{~A}$ role for CD4 cells is implied from the reported remission of gastrointestinal symptoms with progressive $\mathrm{HIV}$ infection in a CD patient. ${ }^{255}$ Alteration in immunoregulation relating to suppressor cell activity has been observed in CD patients. Induction of suppressor cell activity of peripheral blood mononuclear cells (PBMC) by concanavalin $\mathrm{A}$ was reduced with a loss of function correlating to disease activity. ${ }^{256} \mathrm{~A}$ deficiency of suppression of proliferation of autologous lymphocytes was noted in CD patients with active but not quiescent disease. ${ }^{257}$ Minor abnormalities of suppressor activity were noted in two relatives in a genetic study of $\mathrm{T}$ and $\mathrm{B}$ cells of peripheral blood in quiescent CD patients and relatives, but no differences were found for natural killer activity and proliferative responses. $^{257}$

There are reports that PBL may not be an accurate reflection of the lymphocytes in the diseased tissue. Immunological abnormalities exhibited by $\mathrm{PBL}$ are secondary to CD and are related to duration, severity, nutritional status and therapy. ${ }^{62}$ Other studies comparing PBL with lymphocytes from a solid organ compartment, such as the intestine, show that lymphocytes from different organs often have specialised biological functions. ${ }^{258,259}$ However, a study comparing responses of $\mathrm{T}$ lymphocyte from peripheral blood, inflamed tissue and non-inflamed tissue to microbial antigens reported that proliferative responses from inflamed tissue and peripheral blood were similar, whereas $\mathrm{T}$ cells from non-inflamed tissue were unresponsive. ${ }^{260}$ Studies of intestinal mononuclear cells (MC) are inconclusive, with reports of increased ${ }^{261}$ and decreased ${ }^{262}$ suppressor cell activity. The reaction of both PBMC and mesenteric lymph 
node mononuclear cells (MLNMC) in a lymphocyte proliferation assay with various antigens, including some of mycobacterial origin showed that MLNMC responses to antigens were generally greater than PBMC responses. The study did not show an increased response to mycobacterial antigens, but found evidence for increased CMI to a range of nonmycobacterial antigens, in particular $Y$. enterocolitica, in both PBMC and MLNMC in CD and UC patients. ${ }^{263} \mathrm{~A}$ similar finding was reported in a previous study in which increased reactivity to bacterial antigens was non-specifically influenced by the disease process and could act as a secondary sensitisation process. ${ }^{264}$

The most compelling evidence for potential mycobacterial involvement in $\mathrm{CD}$ has come from phagolysosomes termed " $\mathrm{R}$ " bodies which have been observed in 19 cases of $C D .{ }^{265}$ It has been proposed that these " $R$ " bodies comprise lipid coated bacterial fragments. The suggested species include mycoplasmas, mycobacteria and streptococci because of their requirement for certain lipids. The " $R$ " bodies are thought to act as immunological adjuvants and appear in macrophages in active disease, but not in health. ${ }^{266}$ Roediger suggested that the absence of the " $R$ " bodies in other IBD, the frequency with which $\mathrm{CD}$ occurs in the ileocaecal region where lipid absorption takes place, the success of remission in CD when patients are fed elemental diets which contain primarily vegetable oils that do not promote mycobacterial antigenicity, all support the " $R$ " body hypothesis. ${ }^{265}$ Corroborative evidence comes from a study of the survival of $M$. paratuberculosis in monocytes and monocyte-derived macrophages. Macrophages may not only provide a favourable environment for growth of the bacilli, but also in turn may promote their growth in immature monocytes through local concentrations of cytokines. ${ }^{267}$ The theory is also consistent with the pathology of paratuberculosis, in which there is an association of acid-fast bacteria with macrophages during the early stages. ${ }^{268}$

Studies of CMI neither exclude a mycobacterial aetiology for $\mathrm{CD}$ nor provide conclusive evidence for a role, particularly a specific role for $M$. paratuberculosis. The immunological study of $\mathrm{CD}$ is hampered because of the specific effect of the disease on the intestine making conventional techniques to measure CMI inappropriate. The antigen may be present only transiently and the results of the inflammatory response may mask its presence, as implied from the presence of " $R$ " bodies. If fragments of mycobacterial origin are involved in an adjuvant effect, the application of molecular techniques should facilitate their detection. A recent study successfully used PCR to determine the presence of $M$. tuberculosis and $M$. bovis in macrophages. ${ }^{269}$ This approach could be applied to test the " $R$ " body hypothesis.

\section{The effect of chemotherapy on CD-evidence for a mycobacterial aetiology}

The isolation of $M$. kansasii from lymph nodes of CD patients ${ }^{169}$ instigated a new approach to the treatment of $\mathrm{CD}$. Anti-mycobacterial regimens were administered to $C D$ patients and have met with varied success. Many of the anti-mycobacterial drugs were developed for $M$. tuberculosis. Their efficacy against $M$. paratuberculosis and species of the MAI complex is difficult to assess.

\section{Trials of anti-mycobacterial drugs in $C D$ patients}

Rifampicin and ethambuto ${ }^{270}$ were used in the first trial as they were effective against $M$. kansasii, which was then considered to be a putative aetiological agent of CD. ${ }^{271}$ The results of this double-blind study showed no difference between $\mathrm{CD}$ patients receiving the active drug and those receiving the placebo, as determined from clinical indicators of disease activity. There was no evidence to suggest that subgroups of patients were favourably affected by the regimen. ${ }^{270}$ It has been suggested that although rifampicin is effective against strains of $M$. paratuberculosis, ethambutol was a poor choice because organisms readily develop resistance to it; ${ }^{138}$ effectively, patients received a monotherapy regimen which is inefficient in treating mycobacterial disease. However, the authors who criticised the use of monotherapy reported on the efficacy of rifabutin alone, as well as in combinations with other drugs, in the treatment of paratuberculosis in non-human primates. ${ }^{151}$ Other studies with rifabutin alone, or in conjunction with ethambutol or isoniazid, have failed to achieve long term remission from $C D$, and often the trials have been terminated prematurely because of toxic effects. ${ }^{272,273}$ Disappearance of acidfast bacilli from colon biopsies was observed during remission in a CD patient; relapse of the disease was not accompanied by the appearance of the acid-fast bacilli. The patient responded to sulphasalazine and corticosteroid therapy. The authors assumed that the acid-fast bacilli were mycobacteria and suggested that they may play a collateral role in CD. ${ }^{273}$ However, they may have represented other bacteria sensitive to the antibiotic regimen.

There have been reports of remission in $\mathrm{CD}$ patients with anti-mycobacterial chemotherapy. ${ }^{274-277}$ Quadruple therapy of rifampicin, ethambutol and isoniazid with the addition of pyrazinamide or clofazamine produced remission in 10 of $22 \mathrm{CD}$ patients. At the time of the report, the patients were still in remission after 9 months and no toxic side-effects were evident. ${ }^{278}$ Dapsone, which is widely used in the treatment of leprosy, was administered to five CD patients. Remission occurred in two patients. Concurrent with remission was the presence of high antibody titres to $M$. paratuberculosis and not to other mycobacterial species including the MAI complex. High antibody titres to $M$. tuberculosis were reported after treatment 
of tuberculosis with rifampicin. ${ }^{279}$ The authors concluded that $M$. paratuberculosis, or a bacterial species sharing the same antigens, may cause $C D$ in some cases. ${ }^{280}$

\section{Efficacy of anti-mycobacterial drugs against the MAI complex}

The inconsistent results of anti-mycobacterial therapy suggest that a mycobacterial aetiology may be implied for some, but not all cases of $\mathrm{CD}$; this would concur with the hypothesis of an heterogeneous pathology in $\mathrm{CD}^{69,281} \mathrm{It}$ is argued that administration of anti-mycobacterial therapy to those CD patients who do not belong to the group with a mycobacterial aetiology would mask this relationship, which assumes that the therapeutic agents are specific for mycobacteria, in particular M. paratuberculosis or the MAI complex. The agents used in these studies were developed for $M$. tuberculosis; inhibition of the MAI complex is highly variable. Rifampicin and isoniazid inhibit $50 \%$ and $10-30 \%$ of MAI complex strains, respectively; the effect of ethambutol is highly variable and stepwise resistance often develops. ${ }^{282}$ Streptomycin and isoniazid are most active against the MAI complex in log phase. ${ }^{283}$ Clofazimine is reputedly highly effective against MAI complex organisms. ${ }^{12,284}$ There are no reports of the effect of pyrazinamide, but metabolically inactive tubercle bacilli are resistant to it and it is generally ineffective in long-term therapy.

In a comprehensive screen of the susceptibility of 170 mycobacterial strains representing 17 species, sulphasalazine and related compounds, including dapsone, were ineffective against 60 strains of slow growing mycobacteria which included the MAI complex. ${ }^{285}$ The various combinations effective against the MAI complex may offer some explanation for the different successes of these studies. The presence of plasmids in many MAI complex strains ${ }^{286}$ may contribute to antimicrobial resistance, especially when used for long-term therapy. In the most successful study, ${ }^{278}$ clofazimine, probably the most effective drug against the MAI complex, was substituted if any other proved unsuitable. The authors did not indicate the frequency with which this occurred, or the patients involved. In view of the proposed link of the MAI complex with $\mathrm{CD}$, it would be interesting to know whether clofazimine was used in the patients in whom remission was reported.

The results of the sulphasalazine study suggesting that this drug is active against another bacterial agents, or that it has an anti-inflammatory effect, are interesting, as this drug is part of the mainstay therapy for CD patients. ${ }^{287}$ Inflammation is the consequence of $\mathrm{CD}$, not the cause, but control of inflammation results in marked improvement. Bovine zinc copper superoxide dismutase (SOD), an anti-inflammatory drug, achieved remission for 8 years in 19 of 26 patients. Antimicrobial agents were not used in this study. ${ }^{288}$ The levels of SOD are decreased in inflamed tissue in
CD patients ${ }^{289}$ and these studies suggest that there is decreased endogenous protection against oxygenderived radicals in $\mathrm{CD}$. This is consistent with reports of increased levels of eicosanoids derived from arachidonic acid metabolism in CD patients. ${ }^{290-292}$ Sulphasalazine and its derivative 5-aminosalicylic acid affect arachidonic acid metabolism and, in particular, synthesis of prostaglandin (PG) and leukotriene (LT) which are pro-inflammatory agents. ${ }^{293} \mathrm{LT}$ may be more important than PG in CD. ${ }^{294}$ In particular, levels of $\mathrm{LT}_{4}$ are significantly higher in both $\mathrm{UC}$ and $\mathrm{CD}$ patients than in controls ${ }^{295}$ and are responsible for the chemotaxis of neutrophils into the inflamed tissue. ${ }^{296}$ High levels of free radicals may also explain the increased chromosomal breakage which occurs in lymphocytes of CD patients. ${ }^{297}$

Although the chemotherapy data do not exclude mycobacterial involvement in some cases of $C D$, neither do they provide definitive proof. Clearly their role, if any, is only contributory as demonstrated from the results of therapeutic regimens with antimicrobial and anti-inflammatory agents. The factors governing the success of these regimens in some cases, but not in others, still elude clinicians. The success of some antimycobacterial regimens in treating $\mathrm{CD}$ may indicate that $\mathrm{CD}$ comprises of a heterogeneous group of disease, with a mycobacterial aetiology for certain subgroups.

\section{Animal models of $\mathrm{CD}$}

Studies of the factors involved in the pathogenesis of $\mathrm{CD}$ would be facilitated by the development of a suitable animal model. Attempts have been made to reproduce the clinical disease in animals with homogenates from $\mathrm{CD}$ tissue and with mycobacterial species, including both environmental isolates from the MAI complex and isolates from $C D$ or related disease. CBA mice given homogenates of $C D$ tissue developed granulomatous lesions confined to the bowel or mesenteric lymph nodes. The disease was simulated when homogenates were filtered through a $0 \cdot 2-\mu \mathrm{m}$ filter, which would not preclude bacteria without a cell wall, but not when homogenates were autoclaved..$^{298}$ Injection of $M$. kansasii into five immunologically different types of mice, including $\mathrm{BALB} / \mathrm{b}$ by several unspecified routes failed to reproduce the disease. ${ }^{169}$ Four strains of atypical mycobacteria isolated from wood-pigeons with granulomatous disease, which had not been agglutinated by antisera to strains of $M$. avium, were tested for pathogenicity along with two JD isolates of $M$. paratuberculosis. A clinical granulomatous disease ensued with all six strains in mice and with the four atypical wood-pigeon strains in chickens. In calves, three of the four wood-pigeon strains and $M$. paratuberculosis strains each produced clinical JD. ${ }^{191}$

Strains of the MAI complex from animal and environmental sources were tested for their ability to 
produce intestinal lesions after injection into chickens, mice, rabbits, guinea-pigs and calves. Lesions were observed only in calves with mycobactin-dependent $M$. avium and $M$. paratuberculosis. These species and $M$. intracellulare were also recovered from lymph nodes of infected animals. However, these clinical conditions occurred only with some strains of these species and not in every calf. ${ }^{11} M$. avium isolates from swine lymph nodes showing granulomatous tuberculoid features were pathogenic for mice, causing granulomatous lesions in the liver and spleen, but not for chickens. ${ }^{299}$ These studies indicate that both strain and host factors are important in the pathogenesis of paratuberculosis.

The human CD isolate, strain Linda, produced symptoms resembling $C D$ when injected by a number of routes into BALB/c mice, but not in other laboratory species. ${ }^{132,133}$ It also caused a granulomatous disease in Leghorn chickens ${ }^{274}$ and in infant goats fed cream with $10^{7} \mathrm{cfu} / 100 \mathrm{ml}$-this inoculum size is reported to produce JD in ruminants. ${ }^{300}$ Appropriate control animals did not develop symptoms of the disease nor were acid-fast bacteria cultured. ${ }^{132,274,300}$ In goats, the earliest lesion was a cluster of eosinophilic macrophages between the lymphoid nodules and the muscularis mucosa and occurred in the ileum. Giant cells were evident adjacent to the granulomas. Despite the sparsity of acid-fast bacilli in intestinal tissue, strain Linda was recovered from intestinal segments. ${ }^{300}$ The type strain of $M$. paratuberculosis and strain Linda produce identical RFLP profiles when probed with $E$. coli $5 \mathrm{~S}$ rRNA. ${ }^{152}$ In contrast to strain Linda, mycobacterial isolates from CD tissue, $M$. paratuberculosis strain 410 and $M$. chelonei strain 390 did not cause JD in goats. ${ }^{176}$ The designation of $M$. paratuberculosis strain 410 was achieved by phenotype, not genotype, and may not be reliable, explaining its inability to cause paratuberculosis in goats. $M$. chelonei isolates from $\mathrm{CD}$ patients did not simulate $\mathrm{CD}$ when injected into mice. ${ }^{173}$

A wasting disease with intestinal lesions was produced in SCID mice inoculated intraperitoneally, and to a lesser extent when fed orally, with a bacterial suspension prepared from an intestinal segment of a cow with $\mathrm{JD}$. The presence of granulomas and giant cells were rare in SCID mice, but acid-fast bacteria were prevalent in the liver and spleen and later were associated with $\mathrm{MC}$ in the intestinal submucosa ${ }^{301}$ Neonatal rabbits infected orally with $M$. paratuberculosis developed granulomatous enteritis. Although the organisms were cultured from tissue, complement fixation and delayed-type hypersensitivity tests failed to detect infection. ${ }^{302}$ Disease with similar, but not identical, clinical and pathological symptoms to paratuberculosis has been described in several animal hosts when MAI complex isolates have been administered orally or intraperitoneally. The variable symptoms and susceptibilities of hosts, for instance with breeds of mice, indicate that immune status, host species and mycobacterial strain are all important.
Therefore, although the pathogenesis of CD differs in several respects from paratuberculosis in animals, studies of animals models do not exclude a mycobacterial aetiology.

\section{Conclusions}

Epidemiological studies have provided insight into putative aetiological factors for $\mathrm{CD}$. The increased incidence of $\mathrm{CD}$ in certain geographic areas and the variation of incidence within high risk races consuming different diets suggest an environmental aetiology. The increased incidence in what are considered shared environments, e.g., in populations and in families, the infrequent occurrence of $\mathrm{CD}$ in spouses, in migrants and in races of different origin but now in the same geographic location, and the higher incidence in monozygotic twins than in dizygotic twins, lends credence to the hypothesis of an inherited aetiology. Epidemiological evidence for CD supports both environmental and inherited factors, i.e., a multifactorial aetiology.

The potential role of bacteria as aetiological agents has been investigated. The evidence for a mycobacterial aetiology is more compelling than that obtained from studies of the indigenous flora and other bacterial pathogens. However, a synergic effect involving several bacterial species cannot be excluded. The main evidence for an aetiological role for bacteria comes from the quantitative rather than qualitative antibody studies. The presence, or elevated levels, of serum antibodies may be a consequence of patients with $C D$ having greater exposure to the indigenous flora as a result of the inflammation, or being at greater risk from, or more susceptible to, bacterial pathogens. Without prospective studies, the significance of these factors is difficult to assess.

The evidence for a mycobacterial aetiology is more substantial. Although there are many inconsistencies in isolation and culture from different studies, mycobacteria with and without cell walls have been isolated from $\mathrm{CD}$ tissue. These isolates have most frequently belonged to the MAI complex, but precise speciation of the isolates as $M$. paratuberculosis was lacking. Arguably, the high DNA homology, the identical antigenicity and the production of a granulomatous disease, which shares some pathological features with $\mathrm{CD}$, when either $M$. avium or $M$. paratuberculosis is administered to neonatal animals suggests that either species is a possible aetiological candidate for CD. However, despite their high genomic identity, strains of these species differed in their ability to cause granulomatous disease and often were host specific.

The diagnosis of $\mathrm{CD}$ does not parallel the situations in other mycobacterial disease. Serum antibodies are found in tuberculosis and leprosy, and in JD are detected in the advanced stages, but not always in the subclinical disease. Despite considerable effort, antibody to $M$. paratuberculosis has not been detected in $\mathrm{CD}$ patients. There is some circumstantial evidence for 
a mycobacterial aetiology from CMI studies. Positive culture of $M$. paratuberculosis still provides the most reliable diagnosis for $\mathrm{JD}$, but has been inconsistent in CD. However, new diagnostic techniques based on PCR have been developed for mycobacterial diseases such as leprosy and sarcoidosis where culture of the organisms has met with little success. $M$. paratuberculosis and $M$. avium DNA has been detected in some but not all PCR studies of cultured CD tissue samples - albeit at $10^{5}$-fold lower concentration than occur in JD. In some mycobacterial disease, there are reports of mycobacteriophages which produce nonculturable atypical forms. This has not been investigated in $\mathrm{CD}$ and may provide an explanation why mycobacteria, if present, remain elusive to culture. Further studies applying molecular biology techniques and the specific probes developed for $M$. paratuberculosis and the MAI complex should establish whether both, or either of these species are commonly present in $C D$ tissue and clarify their putative aetiological role in $\mathrm{CD}$. They may also provide information on the classification of IT, particularly with respect to the hypertrophic form of IT and its relationship with $\mathrm{CD}$. However, confirmation of presence, especially at the low levels at which $M$. paratuberculosis has been detected in CD tissue, does not provide irrefutable evidence for an aetiological role in $\mathrm{CD}$. These organisms have been detected in control colonic tissue, albeit less frequently. A systematic investigation of the prevalence of these organisms in

\section{References}

1. Kirsner JB. Inflammatory bowel disease. Part I: Nature and pathogenesis. Dis Mon 1991; 37: 605-666.

2. Kinnear WJ. Crohn's disease affecting the nasal mucosa. $J$ Otolaryngol 1985; 14: 399-400.

3. Cameron DJ. Upper and lower gastrointestinal endoscopy in children and adolescents with Crohn's disease: a prospective study. J Gastroenterol Hepatol 1991; 6: 355-358.

4. Kyle J. Rare complications of Crohn's (Dalziel's) disease. Aust NZ J Surg 1991; 61 : 489-492.

5. Rickert RR. The important "impostors" in the differential diagnosis of inflammatory bowel disease. $J$ Clin Gastroenterol $1984 ; 6$ : 153-163.

6. Chiodini RJ. Crohn's disease and the mycobacterioses: a review and comparison of two disease entities. Clin Microbiol Rev $1989 ; 2: 90-117$.

7. Fireman Z, Grossman A, Lilos $\mathbf{P}$ et al. Intestinal cancer in patients with Crohn's disease. A population study in central Israel. Scand J Gastroenterol 1989; 24: 346-350.

8. Fireman Z, Grossman A, Lilos P, Eshchar Y, Theodor E, Gilat T. Epidemiology of Crohn's disease in the Jewish population of central Israel, 1970-1980. Am J Gastroenterol $1989 ; 84: 255-258$.

9. Jewell DP. Crohn's disease. In: Weatherall DJ, Ledingham JGG, Warrell DA (eds) Oxford textbook of medicine, 2nd edn. Oxford, Oxford University Press. 1987: 12.12112.126 .

10. Weterman IT, Pena AS. Familial incidence of Crohn's disease in The Netherlands and a review of the literature. Gastroenterology 1984: 86: 449 452

11. Collins $\mathrm{CH}$, Grange JM. The bovine tubercle bacillus. $J$ Appl Bacteriol 1983; 55: 13-29.

12. Greene JB, Sidhu GS, Lewin S. Mycobacterium aviumintracellulare: a cause of disseminated life-threatening infection in homosexuals and drug abusers. Ann Intern Med 1982; 97: 539-546. different locations of the gut is needed. A molecular approach is also required to elucidate whether mycobacterial fragments reside inside $\mathrm{MNC}$ and act as adjuvants.

It is important that future studies are both comprehensive and strategically directed. Few studies have correlated results with clinical details of the patients that might enable the association of mycobacteria with a particular subgroup. For example, if a parallel is to be drawn between JD and CD, it may be expected that $\mathrm{CD}$ and mycobacterial infection would be more common among the adolescent group of $\mathrm{CD}$ sufferers. The existence of subgroups within $C D$ is suggested from studies of anti-mycobacterial therapy, if it can be assumed that the effects were specific. In this respect it would be interesting to known whether the patients who responded to SOD therapy formed a distinct CD subgroup, the effects of SOD being non-specific. Cluster analyses of epidemiological data have indicated that $C D$ patients form two distinct groups.

Although, $C D$ is pathologically similar to $\mathrm{JD}$, it is clinically different in many respects. The case for mycobacteria, and more specifically $M$. paratuberculosis, as the aetiological agent of $\mathrm{CD}$, can neither be proved nor disproved. Further research is required to clarify whether these organisms play a causative role in the aetiology of $\mathrm{CD}$.

I thank Sam Duerden for assistance with references, Ailsa McGinty for helpful comments and W. Gauld for encouragement, comment and interest.

13. Zakowski P, Fligiel PS, Berlin OGW, Johnson BL. Disseminated Mycobacterium avium-intracellulare infection in homosexual men dying of acquired immunodeficiency. JAMA 1982; 248: 2980-2982.

14. Schneebaum CW, Novick DM, Chabon AB, Strutynsky N, Yancovitz SR, Freund S. Terminal ileitis associated with Mycobacterium avium-intracellulare infection in a homosexual man with acquired immune deficiency syndrome. Gastroenterology 1987; 92: 1127-1132.

15. Thorel MF, Krichevsky M, Levy-Frebault VV. Numerical taxonomy of mycobactin-dependent mycobacteria, emended description of Mycobacterium avium, and description of Mycobacterium avium subsp. avium subsp. nov., and Mycobacterium avium subsp. paratuberculosis subsp. nov., and Mycobacterium avium subsp. silvaticum subsp. nov. Int J Syst Bacteriol 1990; 40: 254-260.

16. Saxegaard F, Baess I. Relationship between Mycobacterium avium, Mycobacterium paratuberculosis and "wood pigeon mycobacteria", Determination by DNA-DNA hybridization. APMIS 1988; 96: 37-42.

17. Saxegaard F, Baess I, Tzen E. Characterization of clinical isolates of Mycobacterium paratuberculosis by DNA-DNA hybridization and cellular fatty acid analysis. APMIS $1988 ; 96: 497-502$

18. Rogall T, Wolters J, Flohr T, Bottger EC. Towards a phylogeny and definition of species at the molecular level within the genus Mycobacterium. Int J Syst Bacteriol 1990; 40: 323-330.

19. Boddinghaus B, Wolters J, Heikens W, Bottger EC. Phylogenetic analysis and identification of different serovars of Mycobacterium intracellulare at the molecular level. FEMS Microbiol Lett 1990; 70: 197-203.

20. Thoreson OF, Saxegaard F. Gen-Probe rapid diagnostic system for the Mycobacterium-avium complex does not distinguish between Mycobacterium avium and Mycobacterium paratuberculosis. J Clin Microbiol 1991; 29: 625-626.

21. Morgan KL. Johne's and Crohn's. Chronic inflammatory bowel 
diseases of infectious aetiology? Lancet 1987; 1: $1017-1019$.

22. Hermon-Taylor J, Moss M, Tizard M, Malik Z, Sandeson J. Molecular biology of Crohn's disease mycobacteria Baillieres Clin Gastroenterol 1990; 4: 23-42.

23. Graham DY, Markesich DC, Yoshimura HH. Mycobacteria and inflammatory bowel disease. Results of culture. Gastroenterology 1987; 92 : 346-342.

24. Wolinsky E, Rynearson TK. Mycobacteria in soil and their relation to disease-associated strains. Am Rev Respir Dis 1968; 97: 1032-1037.

25. Sonnenberg A. Geographic variation in the incidence of and mortality from inflammatory bowel disease. Dis Colon Rectum 1986; 29: 854-861.

26. de Dombal FT. Epidemiology of Crohn's disease of the colon. Ann Gastroenterol Hepatol 1985; 21: 191-200.

27. Calkins BM, Mendeloff AI. Epidemiology of inflammatory bowel disease. Epidemiol Rev 1986; 8: 60-91.

28. Higashi A, Watanabe Y, Ozasa K, Hayashi K, Aoike A, Kawai $\mathrm{K}$. Prevalence and mortality of ulcerative colitis and Crohn's disease in Japan. Gastroenterol Jap 1988; 23 : 521-526.

29. Binder V. Epidemiology, course and socio-economic influence of inflammatory bowel disease. Schweiz Med Wochenschr 1988; 118: 738-742.

30. Barton JR, Gillon S, Ferguson A. Incidence of inflammatory bowel disease in Scottish children between 1968 and 1983, marginal fall in ulcerative colitis, three-fold rise in Crohn's disease. Gut 1989; 30: 618-622.

31. Calkins BM, Lilienfeld AM, Garland CF, Mendeloff AI. Trends in incidence rates of ulcerative colitis and Crohn's disease. Dig Dis Sci 1984; 29: 913-920.

32. Sandler RS, Golden AL. Epidemiology of Crohn's disease. $J$ Clin Gastroenterol 1986; 8: 160-5.

33. Brahme F, Lindstrom C, Wenckert A. Crohn's disease in a defined population. An epidemiological study of incidence, prevalence, mortality, and secular trends in the city of Malmo, Sweden. Gastroenterology 1975; 69: 342-351.

34. Kyle J, Stark G. Fall in the incidence of Crohn's disease. Gut $1980 ; 21: 340-343$.

35. Centers for Disease Control. 1989 tuberculosis statistics in the United States. US Department of Health and Human Services, Public Health Service. 1991: 10-11.

36. Sathe S, Sarai A. Mycobacterial infections. Curr Opin Infect Dis $1992 ; 5: 176-182$

37. Kildebo S, Breckan R, Nordgaard K, Burhol PG, Jorde R. The incidence of Crohn's disease in northern Norway from 1983 to 1986. Scand J Gastroenterol 1989; 24: 1265-1270.

38. Pinchbeck BR, Kirdeikis J, Thomson AB. Inflammatory bowel disease in northern Alberta. An epidemiologic study. J Clin Gastroenterol 1988; 10: 505-515.

39. Gilat T, Rozen P. Epidemiology of Crohn's disease and ulcerative colitis: etiologic implications. Isr J Med Sci $1979 ; 15$ : 305-308.

40. Mayberry JF, Judd D, Smart H, Rhodes J, Calcraft B, Morris JS. Crohn's disease in Jewish people - an epidemiological study in south-east Wales. Digestion 1986; 35: 237-240.

41. Wright JP, Froggatt J, O'Keefe EA et al. The epidemiology of inflammatory bowel disease in Cape Town 1980-1984. $S$ Afr Med J 1986; 70: 10-15.

42. Roth MP, Petersen GM, McElree C, Vadheim CM, Panish JF, Rotter JI. Familial empiric risk estimates of inflammatory bowel disease in Ashkenazi Jews. Gastroenterology 1989; 96: 1016-1020

43. Odes HS, Fraser D, Krawiec J. Inflammatory bowel disease in migrant and native Jewish populations of southern Israel. Scand J Gastroenterol Suppl 1989; 170: 36-38, 50-55.

44. Odes HS, Fraser D, Hollander L. Epidemiological data of Crohn's disease in Israel: etiological implications. Public Health Rev 1989; 17: 321-335.

45. Odes HS, Fraser D, Krugliak P, Fenyves D, Fraser GM, Sperber AD. Inflammatory bowel disease in the Bedouin Arabs of southern Israel: rarity of diagnosis and clinical features. Gut 1991; 32: 1024-1026.

46. Al-Nakib B, Radhakrishnan S, Jacob GS, Al-Liddawi H, AlRwaih A. Inflammatory bowel disease in Kuwait. Am J Gastroenterol 1984; 79: 191-194.

47. Krawiec J, Odes HS, Lasry Y, Krugliak P, Weitzman S. Aspects of the epidemiology of Crohn's disease in the Jewish population in Beer Sheva, Israel. Isr J Med Sci 1984; 20 : $16-21$

48. Zlotogora J, Zimmerman J, Rachmilewitz D. Prevalence of inflammatory bowel disease in family members of Jewish Crohn's disease patients in Israel. Dig Dis Sci 1991: 36: $471-475$

49. Rozen P, Zonis J, Yekutiel P, Gilat T. Crohn's disease in the Jewish population of Tel-Aviv-Yafo. Epidemiologic and clinical aspects. Gastroenterology 1979; 76: 25-30.

50. Roth MP, Petersen GM, McElree C, Feldman E, Rotter JI Geographic origins of Jewish patients with inflammatory bowel disease. Gastroenterology 1989; 97: 900-904

51. Mayberry JF. Recent epidemiology of ulcerative colitis and Crohn's disease. Int J Colorectal Dis 1989; 4: 59-66.

52. Dua KS, Mowat NA. Familial Crohn's disease, including spouse. Scott Med J 1988; 33: 372-373.

53. Rosenberg JL, Jraft SC, Jirsner JB. Inflammatory bowel disease in all three members of one family. Gastroenterology 1976; 70: $759-760$

54. Whorwell PJ, Eade OE, Gossenbocus A, Bamforth J. Crohn's disease in a husband and wife. Lancet 1978; 2 : 186-187.

55. Mayberry JF, Rhodes J, Newcombe RG. Familial prevalence of inflammatory bowel disease in relative of patients with Crohn's disease. BMJ 1980; 1: 84 .

56. Hellers G. Crohn's disease in Stockholm County 1955-1974. Acta Chir Scand Suppl 1979; 490: 5-82.

57. Purrmann J, Gleveland S, Hengels KJ. Investigations of various inheritance models in Crohn's disease. Z Gastroenterol 1991; 29: 276-282.

58. Singer HC, Anderson JGD, Frischer H, Kirsner JB. Familial aspects of inflammatory bowel disease. Gastroenterology $1971 ; 61: 423-430$.

59. Lashner BA, Evans AP, Kirsner JB, Hanauer SB. Prevalence and incidence of inflammatory bowel disease in family members. Gastroenterology 1986; 91 : 1396-1400.

60. Monsen U. Inflammatory bowel disease. An epidemiological and genetic study. Acta Chir Scand Suppl 1990; 559: 1-42.

61. Farmer RG, Michener WM, Sivak DS. Studies of family history in inflammatory bowel disease. In: Pena AS, Weterman IT. Booth CC, Strober W (eds) Recent advances in Crohn's disease. Developments in gastroenterology, vol. 1. The Hague, Martinus Nijhoff. 1981: 213-218.

62. MacDermott RP, Stenson WF. Alterations of the immune system in ulcerative colitis and Crohn's disease. $A d v$ Immunol 1988; 42: 285-328.

63. Eade OE, Moulton C, MacPherson BR, Andre-Ukena SS, Albertini RJ. Discordant HLA haplotype segregation in familial Crohn's disease. Gastroenterology 1980: 79: 271-275.

64. Delpre G, Kadish U, Gazit E, Joshua H, Zamir R. HLA antigens in ulcerative colitis and Crohn's disease in Israel. Gastroenterology 1980; 78: 1452-1457.

65. Colombel JF, Guillemot F, Van Gossum A et al. Familial Crohn's disease in multiple siblings: no linkage to the HLA system. Gastroenterol Clin Biol 1989; 13: 676-678.

66. Biemond I, Burnham WR, D'amaro J, Langman MJ. HLA-A and -B antigens in inflammatory bowel disease. Gut 1986; 27: 934-941.

67. Kagnoff MF, Brown RJ, Schanfield MS. Association between Crohn's disease and immunoglobulin heavy chain $(\mathrm{Gm})$ allotypes. Gastroenterology 1983; 85: 1044-1047.

68. Gudjonsson H, Schanfield MS, Albertini RJ, McAuliffe TL, Beeken WL, Krawitt EL. Association and linkage studies of immunoglobulin heavy chain allotypes in inflammatory bowel disease. Tissue Antigens $1988 ; 31: 243-249$.

69. Prantera C, Berto E, Scribano ML. Mycobacteria and subgroups of patients in Crohn's disease. Ital J Gastroenterol $1991 ; 23: 49-51$.

70. Beaugerie L, Le Quintrec Y, Paris JC et al. Testing for course patterns in Crohn's disease using clustering analysis. Gastroenterol Clin Biol 1989; 13: 1036-1041.

71. Harris ML, Bayless TM. Dietary antigens as aggravating factors in Crohn's disease. Dig Dis Sci 1989; 34: 1613-1614.

72. Bjarnason I, O'Morain C, Lev, AJ, Peters TJ. Absorption of 51 Chromium labelled ethylenediaminetetraacetate. Gastroenterology $1983 ; 85$ : 318-322.

73. Davidson IW, Lloyd RS, Whorwell PJ, Wright R. Antibodies to maize in patients with Crohn's disease, ulcerative colitis and coeliac disease. Clin Exp Immunol 1979; 35: 147-148

74. Knoflach P, Park BH, Cunningham R, Weiser MM, Albini B. 
Serum antibodies to cow's milk proteins in ulcerative colitis and Crohn's disease. Gastroenterology 1987; 92: 470-485.

75. Biancone L, Paganelli R, Fais S et al. Peripheral and intestinal lymphocyte activation after in vitro exposure to cow's milk antigens in normal subjects and in patients with Crohn's disease. Clin Immunol Immunopathol 1987; 45: 491-498.

76. Chao LP, Steele J, Rodrigues C et al. Specificity of antibodies secreted by hybridomas generated from activated $\mathrm{B}$ cells in the mesenteric lymph nodes of patients with inflammatory bowel disease. Gut 1988; 29: 35-40.

77. Gilat T, Hacohen D, Lilos P, Langman MJ. Childhood factors in ulcerative colitis and Crohn's disease. An international cooperative study. Scand J Gastroenterol 1987; 22: 1009-1024.

78. Bergstrand $\mathrm{O}$, Hellers $\mathrm{G}$. Breast-feeding during infancy in patients who later develop Crohn's disease. Scand $J$ Gastroenterol 1983; 18: 903-906.

79. O'Morain C. Diet and Crohn's disease. Mol Aspects Med 1987 9: $113-118$

80. Martini GA, Brandes JW. Increased consumption of refined carbohydrates in patients with Crohn's disease. Klin Wochenschr 1976; 54: 367-371.

81. Sonnenberg A. Geographic and temporal variations of sugar and margarine consumption in relation to Crohn's disease. Digestion 1988; 41: 161-171.

82. Nanji AA, Denardi FG. Primary adult lactose intolerance protects against development of inflammatory bowel disease. Med Hypotheses 1986; 19: 1-6.

83. Postuma R, Moroz SP. Pediatric Crohn's disease. J Ped Surg $1985 ; 20: 478-482$.

84. Afdhal NH, Kelly J, McCormick PA, O'Donoghue DP. Remission induction in refractory Crohn's disease using a high calorie whole diet. J Parenter Enteral Nutr $1989 ; 13$ : $362-365$.

85. Ritchie JK, Wadsworth J, Lennard-Jones JE, Rogers E Controlled multicentre therapeutic trial of an unrefined carbohydrate, fibre rich diet in Crohn's disease. $B M J 1987$; 295: $517-520$.

86. Best WR, Becktel GM, Singletone JW. Development of a Crohn's diseases activity index. Gastroenterology 1976; 70 439-444.

87. Giaffer MH, Holdsworth CD, Duerden BI. The assessment of faecal flora in patients with inflammatory bowel disease by a simplified bacteriological technique. $J$ Med Microbiol $1991 ; 35$ : 238-243.

88. Horing E, Gopfert D, Schroter G, von Gaisberg U. Frequency and spectrum of microorganisms isolated from biopsy specimens in chronic colitis. Endoscopy 1991 ; 23: 325-327.

89. Ambrose NS, Johnson M, Burdon DW, Keighley MR. Incidence of pathogenic bacteria from mesenteric lymph nodes and ileal serosa during Crohn's disease surgery. $\mathrm{Br} J$ Surg 1984; 71 : 623-625.

90. Wensinck F. The faecal flora of patients with Crohn's disease. Antonie Van Leeuwenhoek $1975 ; 41: 214-215$.

91. Wensinck F. Faecal flora of Crohn's patient. Serological differentiation between Crohn's disease and ulcerative colitis. In: Weterman IT, Pena AS, Booth CC (eds) The management of Crohn's disease. Amsterdam, Excerpta Medica. 1976; 103-106.

92. Van de Merwe JP, Schmitz PIM, Wensinck F. Antibodies to Eubacterium and Peptostreptococcus species and the estimated probability of Crohn's disease. $J H y g ~ 1981 ; 87$ : $25-33$.

93. Matthews N, Mayberry JF, Rhodes J et al. Agglutinins to bacteria in Crohn's disease. Gut $1980 ; 21$ : 376-380.

94. Howells B, Matthews N, Mayberry JF, Rhodes J. Agglutinins to anaerobic bacteria in Crohn's disease and in Indian patients with diarrhoea. $J$ Med Microbiol 1984; 17 207-209.

95. Brown WR, Lee E. Radioimmunological measurement of bacterial antibodies 1: Human serum antibodies reactive with Bacteriodes fragilis and Enterococcus in gastrointestinal and immunological disorders. Gastroenterology 1974; 66: 1145-1158

96. Thayer WR, Brown M, Sangree H, Katz J, Hersh T. Escherichia coli $\mathrm{O}: 14$ and colon hemagglutinating antibodies in inflammatory bowel disease. Gastroenterology 1969; 57: 311-316.

97. Tabaqchali S, O'Donoghue DP, Bettelheim KA. Escherichia coli antibodies in patients with inflammatory bowel disease. Gut 1978; 19: 180-213.
98. Blaser MJ, Miller RA, Lacher J, Singleton JW. Patients with active Crohn's disease have elevated serum antibodies to antigens of seven enteric bacterial pathogens. Gastroenterology $1984 ; 87: 888-894$.

99. Persson S, Danielsson D, Kjellander J, Wallensten S. Studies on Crohn's disease. 1. The relationship between Yersinia enterocolitica infection and terminal ileitis. Acta Chir Scand 1976; 142: 84-90.

100. Forsberg DA, Wall TC, Garbutt JT. When Crohn's disease is not Crohn's disease. NC Med J 1985; 46: 199-200.

101. Manley PN, Dhru R. Actinomycosis complicating Crohn's disease. Gastroenterology 1980; 79: 934-937.

102. Szilagyi A, Gerson M, Mendelson J, Yusuf NA. Salmonella infections complicating inflammatory bowel disease. $J$ Clin Gastroenterol 1985; 7: 251-255.

103. Scheurlen C, Kruis W, Spengler U, Weinzierl M, Paumgartner $\mathrm{G}$, Lamina J. Crohn's disease is frequently complicated by giardiasis. Scand J Gastroenterol 1988; 23: 833-839.

104. Mee AS, Shield M, Burke M. Campylobacter colitis: differentiation from acute inflammatory bowel disease. $J R S o c$ Med 1985; 78: 217-223.

105. Kato Y, Hattori T, Oh-Ya H, Yoshino S, Kato H. Acute terminal ileitis and Yersinia enterocolitica infection. Gastroenterol Jpn 1977; 12: 36-43.

106. Aspestrand F. The early manifestation of Yersinia colitis demonstrated by the double-contrast barium enema. Radiology 1986; 26: 549-551.

107. Payne M, Girdwood AH, Roost RW, Freson MJ, Kottler RE. Yersinia enterocolitica and Crohn's disease. A case report. $S$ Afr Med J 1987; 72 : 53-55.

108. Levine JS, Smith PD, Brugge WR. Chronic proctitis in male homosexuals due to lymphogranuloma venereum. Gastroenterology 1980; 79: 563-565.

109. Schuller JL, Piket-Van UJ, Veeken IVD, Michael MF, Stolz E. Antibodies against chlamydia of lymphogranuloma venereum-type in Crohn's disease. Lancet 1979; 1 : 19-20.

110. Cevenini R, Donati M, Landini MP et al. Antibodies against Chlamydia trachomatis in patients with Crohn's disease. Microbiologica 1980; 3: 109-113

111. Orda R, Samra Z, Levy Y, Shperber Y, Scapa E. Chlamydia trachomatis and inflammatory bowel disease-a coincidence? J R Soc Med 1990; 83: 15-17.

112. Elliott PR, Forsey T, Darougar S, Treharne JD, LennardJones JE. Chlamydiae and inflammatory bowel disease. Gut 1981 ; 22 : 25-27.

113. Taylor-Robinson D, O'Morain CA, Thomas BJ, Levi AJ. Low frequency of chlamydial antibodies in patients with Crohn's disease and ulcerative colitis. Lancet 1979; 1: $1162-1163$.

114. Swarbrick ET, Kingham JG, Price HL et al. Chlamydia, cytomegalovirus, and yersinia in inflammatory bowel disease. Lancet 1979; 2: 11-12.

115. McGarity BH, Robertson DAF, Clarke WR. Deoxyribonucleic acid amplification and hybridisation in Crohn's disease using a chlamydial plasmid probe. Gut 1991; 35 : 1011-1015.

116. Cullen JH. Intestinal tuberculosis. A clinical pathological study. $Q$ Bull Seaview Hosp 1940; 5: 143-160.

117. Hoon JR, Dockerty B, Pemberton J. Ileocecal tuberculosis including a comparison of this disease with non specific regional enterocolitis and noncaseous tuberculated enterocolitis. Int Abs Surg 1950; 91: 417-440.

118. Segal I. Intestinal tuberculosis, Crohn's disease and ulcerative colitis in an urban black population. $S$ Afr Med J 1984; 65: $37-44$

119. Kovalyov GK. On human tuberculosis due to $M$. boris. A review. J Hyg Epidemiol Microbiol Immunol 1989; 33: 199-206.

120. Tandon HD, Prakash A. Pathology of intestinal tuberculosis and its distinction from Crohn's disease. Gut 1972; 13: 260-269.

121. Carrera GG, Young S, Lewicki AM. Intestinal tuberculosis. Gastrointest Radiol 1976; 1 : 147-155.

122. Abrams JS, Holden WD. Tuberculosis of the gastrointestinal tract. Arch Surg 1964; 89: 282-293.

123. Paustian F, Bockus H. So-called primary ulcerotrophic ileocecal tuberculosis. Am J Med 1959; 27: 509-518.

124. Shah IC. Ileocecal tuberculosis and Crohn's disease. NY State $J$ Med 1973; 73: 949-951.

125. Wig KLN, Chitkara SP, Gupta SP, Kishore K, Manchada RL. 
Ileocecal tuberculosis with particular reference to isolation of Mycobacterium tuberculosis. With a note on its relation to regional ileitis (Crohn's disease). Am Rev Respir Dis 1961; 84: 169-178.

126. Francis J. Infection of laboratory animals with Mycobacterium johnei. J Comp Pathol 1940; 53: 140-149.

127. Doyle TM. Susceptibility to Johne's disease in relation to age. Vet Rec 1953; 65: 363-336.

128. Hagan WA. Age as a factor in susceptibility to Johne's disease. Cornell Vet 1938; 28: $34-40$.

129. Rankin JD. The experimental infection of cattle with $M y c o-$ bacterium johnei. II Adult cattle inoculated intravenously. J Comp Pathol 1961; 71: 6-9.

130. Rankin JD. The experimental infection of cattle with $M y c o-$ bacterium johnei. IV Adult cattle maintained in an infectious environment. J Comp Pathol 1962; 72: 113-117.

131. Brotherston JG, Gilmour NJL. A reappraisal of the pathogenesis and immunity to Mycobacterium johnei in sheep, calves, hamsters and mice using a quantitative bacteriologic technique. In: Proceedings of the Seventeenth World Veterinary Congress. Hanover, 1963: 487-493.

132. Chiodini RJ, Kruiningen HJV, Merkal RS, Thayer WR, Coutu JA. Characteristics of an unclassified $\mathrm{Myco-}$ bacterium species isolated from patients with Crohn's disease. J Clin Microbiol 1984; 20: 966-971.

133. Chiodini RJ, Van Kruiningen HJ, Thayer WR, Merkal RS, Coutu JA. Possible role of mycobacteria in inflammatory bowel disease. I. An unclassified Mycobacterium species isolated from patients with Crohn's disease. Dig Dis Sci 1984; 29: 1073-1079.

134. Dunkin GW. Johne's disease. Its economic significance and early detection. Vet Rec $1935 ; 14: 1551-1559$.

135. Macindoe RHJ. What can we do about Johne's disease? Aust Vet $J$ 1950; 26: 216-220.

136. Larsen AB, Merkal RS, Cutlip RC. Age of cattle as related to resistance to infection with Mycobacterium paratuberculosis. Am J Vet Res 1975; 36: 255-257.

137. Withers FW. Incidence of the disease. Vet Rec 1959; 71 : $1150-1153$.

138. Chiodini RJ, Kruiningen HJV, Merkal RS. Ruminant paratuberculosis (Johne's disease): the current status and future prospects. Cornell Vet $1984 ; 74: 218-262$.

139. Merkal RS, Larsen AB, Kopecky KE, Ness RD. Comparison of examination and test methods for early detection of paratuberculous cattle. Am J Vet Res 1968; 29: $1533-1537$.

140. Taylor TK, Wilks CR, McQueen DS. Isolation of Mycobacterium paratuberculosis from the milk of a cow with Johne's disease. Vet Rec $1981 ; 109: 532-533$.

141. Van der Giessen JWB, Eger A, Haagsma J, Haring RM, Gaastra W, Ven der Zeijst BAM. Amplification of 16SRNA sequences to detect Mycobacterium paratuberculosis. J Med Microbiol 1992; 36: 255-263.

142. Sugden EA, Corner AH, Samagh BS et al. Serodiagnosis of ovine paratuberculosis using lipoarabinomannan in an enzyme-linked immunosorbent assay. Am J Vet Res 1989 50: $850-854$

143. McNab WB, Meek AH, Duncan JR et al. An evaluation of selected screening tests for bovine paratuberculosis. Can J Vet Res 1991; 55: 252-259.

144. Sugden EA, Brooks BW, Young NM et al. Chromatographic purification and characterisation of antigens $A$ and $D$ from Mycobacterium paratuberculosis and their use in enzyme linked immunosorbent assays for diagnosis of paratuberculosis in sheep. $J$ Clin Microbiol 1991; 29: $1659-1664$

145. Abbas B, Riemann HP, Lonnerdal B. Isolation of specific peptides from Mycobacterium paratuberculosis protoplasm and their use in an enzyme-linked immunosorben assay for the detection of paratuberculosis(Johne's disease) in cattle. Am J Vet Res 1983; 44: 2229-2236.

146. Yokomizo Y, Kishima M, Mori Y, Nishimori K. Evaluation of enzyme-linked immunosorbent assay in comparison with complement fixation test for the diagnosis of subclinical paratuberculosis in cattle. J Vet Med Sci 1991; 53: $577-584$

147. McDiarmid A. Diseases of free living wild animals. FAO Agricultural Studies 1962; 57: 10

148. Soltys MA, Wise DR. Atypical Mycobacterium in tuberculosis- like lesions in woodpigeons. $J$ Pathol Bacteriol 1967: 93 : 351-352.

149. Thorel MF, Desmettre P. Comparative study of mycobactindependent strains of mycobacteria isolated from woodpigeon with Mycobacterium avium and $M$. paratuberculosis. Ann Microbiol (Inst Pasteur) 1982; 133B 291-302.

150. Cline JM, Schlafer DW, Callihan DR, Vanderwall D, Drazek FJ. Abortion and granulomatous colitis due to $\mathrm{Myco}$ bacterium avium complex infection in a horse. Vet Pathol $1991 ; 28$ : 89-91.

151. McClure HM, Chiodini RJ, Anderson DC, Swenson RB Thayer WR, Coutu JA. Mycobacterium paratuberculosis infection in a colony of stumptail macaques (Macaca arctoides). $J$ Infect Dis 1987; 155: 1011-1019.

152. Chiodini RJ, Van Kruiningen HJ, Thayer WR, Coutu JA. Spheroplastic phase of mycobacteria isolated from patients with Crohn's disease. J Clin Microbiol 1986: 24: 357-363.

153. Meissner G, Anz W. Sources of Mycobacterium avium complex infection resulting in human diseases. Am Rev Respir Dis 1977; 116: 1057-1064.

154. Kubica GP, Beam RE, Palmer JW. A method for the isolation of unclassified acid-fast bacilli from soil and water. $A m$ Rev Respir Dis 1963; 88: 718 .

155. Jones RJ, Jenkins DE, Hsu KH. Raw milk as a source of mycobacteria. Can J Microbiol 1966; 12: 979-84.

156. Chapman JS, Speight M. Isolation of atypical mycobacteria from pasteurized milk. Am Rev Respir Dis 1968; 98: $1052-1054$.

157. Hosty TS, McDurmont Cl. Isolation of acid-fast organisms from milk and oysters. Health Lab Sci 1975; 12: 16-19.

158. Dunn BL, Hodges DJ. 'Atypical' mycobacteria in milk. $J$ Appl Bacteriol 1982; 52: 373-376.

159. Girdhar A, Girdhar BK, Ramu Get al. Discharge of M. leprae in milk of leprosy patients. Lepr Ind 1989; 53: 390-394.

160. Sweeney RW, Whitlock RH, Rosenberger AE. Mycobacterium paratuberculosis cultured from milk and supramammary lymph nodes of infected asymptomatic cows. $J$ Clin Microbiol 1992; 30: 166-171.

161. Merkal RS, Crawford JA. Heat inactivation of Mycobacterium avium-Mycobacterium intracellulare complex organisms in aqueous suspension. Appl Environ Microbiol 1979; 38: $827-830$.

162. Merkal RS, Crawford JA, Whipple DL. Heat inactivation of Mycobacterium avium-Mycobacterium intracellulare complex organisms in meat products. Appl Environ Microbiol $1979 ; 38$ : 831-835.

163. Merkal RS, Whipple DL. Inactivation of Mycobacterium botis in meat products. Appl Environ Microbiol 1980: 40: 282-284.

164. Merkal RS, Lyle PS, Whipple DL. Heat inactivation of in vivo- and in vitro-grown mycobacteria in meat products. Appl Environ Microbiol 1981; 41: 1484-1485.

165. Thornton $\mathbf{H}$. Textbook of meat inspection including the inspection of rabbits and poultry, 4th edn. London. Bailliere, Tindall and Cassell. 1962.

166. Pavlas M. Thermoresistance of mycobacteria. Acta Vet Brno $1990 ; 59: 65-71$

167. Crohn B, Ginzburg L, Oppenheimer G. Regional ileitis, a pathological and clinical entity. JAMA 1932; 99 1323-1329.

168. Van Patter W. Pathology and pathogenesis of regional enteritis. PhD thesis, University of Minnesota. 1952.

169. Burnham WR, Lennard-Jones JE, Stanford JL, Bird RG Mycobacteria as a possible cause of inflammatory bowel disease. Lancet 1978; 2: 693-696.

170. Mankiewicz E, Van Walbeek M. Mycobacteriophages. Their role in tuberculosis and sarcoidosis. Arch Environ Health $1962 ; 5: 122-8$.

171. Gitnick G, Collins J, Beaman B, Brooks D, Arthur M. Mycobacteria in Crohn's disease. Gastroenterology 1985: 88: 1396

172. Coloe PJ, Wilks CR, Lightfoot D, Tosolini FA. Isolation of a Mycobacterium sp. resembling $M$. paratuberculosis from the bowel tissues of a patient with Crohn's disease. Aust Microbiol 1986; 7: 188

173. Haagsma J, Mulder CJJ, Eger A, Tytgat GNJ. A study of antibodies to Mycobacterium paratuberculosis in inflammatory bowel disease. Preliminary results. In: MacDer- 
mott RP (ed). Inflammatory bowel disease; current status and future approach. Amsterdam, Elsevier. 1988: $539-542$.

174. Colemont LJ, Pattyn SR, Michielsen PP et al. Acid-fast bacilli in Crohn's disease. Lancet 1988; 1: 294-295.

175. Markesich DC, Graham DY, Yoshimura HH. Progress in culture and subculture of spheroplasts and fastidious acid-fast bacilli isolated from intestinal tissues. $J$ Clin Microbiol 1988; 26: 1600-1603.

176. Graham DY, Markesich DC, Yoshimura HH. Mycobacteria as the cause of Crohn's disease. Gastroenterology 1989; 97: $1354-1356$

177. Gitnick G, Collins J, Beaman B et al. Preliminary report on isolation of mycobacteria from patients with Crohn's disease. Dig Dis Sci 1989; 34: 925-932.

178. Bottger EC. Gen-Probe Rapid diagnostic system for distinguishing between Mycobacterium avium and $\mathrm{Myco}$ bacterium paratuberculosis. J Clin Microbiol 1991; 29. 2360-2361.

179. Lambrecht RS, Collins MT. Mycobacterium paratuberculosis: factors that influence mycobactin dependence. Diagn Microbiol Infect Dis 1992; 15: 239-246.

180. Matthews PRJ, Sargent A. The isolation of mycobacteria from the brown hare. Br Vet J 1977; 133: 399-404.

181. Matthews PRJ, McDiarmid A, Collins P, Brown A. The dependence of some strains of Mycobacterium avium on mycobactin for initial and subsequent growth. $J \mathrm{Med}$ Microbiol 1978; 11: 53-59.

182. Collins P, Matthews PR, McDiarmid A, Brown A. The pathogenicity of Mycobacterium avium and related mycobacteria for experimental animals. J Med Microbiol 1983; 16: $27-35$.

183. McFadden JJ, Butcher DP, Thompson J, Chiodini R, HermonTaylor J. The use of DNA probes identifying restrictionfragment-length polymorphisms to examine the $\mathrm{Myco}$ bacterium avium complex. Mol Microbiol 1987; 1: 283-291.

184. Merkal RS, Curran BJ. Growth and metabolic characteristics of Mycobacterium paratuberculosis. Appl Microbiol 1974; 28: $276-279$.

185. Collins DM, DeLisle GW. Restriction endonuclease analysis of various strains of Mycobacterium paratuberculosis isolated from cattle. Am J Vet Res 1986; 47: 2226.

186. Whipple D, Kapke P, Vary C. Identification of restriction fragment length polymorphisms in DNA from $\mathrm{Myco-}$ bacterium paratuberculosis. J Clin Microbiol 1990; 28: 2561-2564.

187. Stahl DA. Urbance JW. The division between fast- and slowgrowing species, corresponds to natural relationships among the mycobacteria. $J$ Bacteriol $1990 ; 172: 116-124$

188. Collins DM, Gabric DM, De Lisle G. Identification of two groups of Mycobacterium paratuberculosis strains by restriction endonuclease analysis and DNA hybridization. $J$ Clin Microbiol 1990; 28: 1591-1596.

189. McFadden JJ, Butcher PD, Chiodini R, Hermon-Taylor J. Crohn's disease-isolated mycobacteria are identical to Mycobacterium paratuberculosis, as determined by DNA probes that distinguish between mycobacterial species. J Clin Microbiol 1987; 25: 796-801.

190. Boddinghaus B, Rogall T, Flohr T, Blocker H, Bottger EC. Detection and identification of mycobacteria by amplification of rRNA. J Clin Microbiol 1990; 28: 1751-1759.

191. McIntyre G, Stanford JL. Immunodiffusion analysis shows that Mycobacterium paratuberculosis and other mycobactin dependent mycobacteria are variants of Mycobacterium avium. J Appl Bacteriol 1986; 61 : 293-298.

192. Matthews PRJ, McDiarmid A. The production in bovine calves of a disease resembling paratuberculosis with a Mycobacterium species isolated from a woodpigeon (Columba palumbus). Vet Rec $1979 ; 104: 286$.

193. Good RC. Diseases in nonhuman primates. In: Kubica GP, Wayne LG (eds) The mycobacteria; a sourcebook. New York, Marcel Dekker. 1984; 903-924.

194. McFadden JJ, Butcher PD, Chiodini RJ, Hermon-Taylor J. Determination of genome size and DNA homology between an unclassified Mycobacterium species isolated from patients with Crohn's disease and other mycobacteria. J Gen Microbiol 1987; 133: 211-214.

195. Yoshimura HH, Graham DY, Estes MK, Merkal RS. Investigation of association of mycobacteria with inflammatory bowel disease by nucleic acid hybridization. $J$ Clin Microbiol 1987; 25: 45-51.

196. Butcher PD, McFadden JJ, Hermon-Taylor J. The use of cloned mycobacterial DNA probes for the detection of mycobacteria in Crohn's disease tissue. Biochem Soc Trans 1987 ; 15 : 547-549.

197. Butcher PD, McFadden JJ, Hermon-Taylor J. Investigation of mycobacteria in Crohn's disease tissue by Southern blotting and DNA hybridisation with cloned mycobacterial genomic DNA probes from a Crohn's disease isolated mycobacteria. Gut 1988; 29: 1222-1228.

198. Green EP, Tizard ML, Moss MT et al. Sequence and characteristics of $I S 900$, an insertion element identified in a human Crohn's disease isolate of Mycobacterium paratuberculosis. Nucleic Acids Res 1989; 17: 9063-9073.

199. Pao CC, Yen B, You JB, Maa SJ, Fiss HE. Detection and identification of Mycobacterium tuberculosis by DNA amplification. J Clin Microbiol 1990; 28: 1877-1880.

200. Saboor SA, Johnson N, McFadden J. Detection of mycobacterial DNA in sarcoidosis and tuberculosis with polymerase chain reaction. Lancet 1992; 339: 1012.

201. Mitchell IC, Turk JL, Mitchell DN. Detection of mycobacterial rRNA in sarcoidosis with liquid-phase hybridisation. Lancet 1992; 339: 1015-1017.

202. Graham DY, Markesich DC, Kalter DC, Moss MT, HermonTaylor J, El-Zaatari FAK. Mycobacterial aetiology of sarcoidosis. Lancet 1992; 340: 52-53.

203. Gerdes J, Ricter E, Greinert U et al. Mycobacterial nucleic acids in sarcoid lesions. Lancet $1992 ; 339$ : 1536-1537.

204. Bocart D, Lecossier D, de Lassence A, Valegre D, Battesti JP. Hance AJ. A search for mycobacterial DNA in granulomatous tissues from patients with sarcoidosis using the polymerase chain reaction. Am Rev Respir Dis 1992: 145: $1142-1148$.

205. Arnoldi J, Schuluter C, Duchrow M et al. TI species-specific assessment of Mycobacterium leprae in skin biopsies by in situ hybridization and polymerase chain reaction. Lab Invest 1992; 66: 618-623.

206. Fries UWJ, Patel JR, Piessens FW, Wirth D. Genus- and species-specific DNA probes to identify mycobacteria using the polymerase chain reaction. Mol Cell Probes $1990 ; 4: 87-105$.

207. Hance JA, Grandchamp B, Levy-Frebault V et al. Detection and identification of mycobacteria by amplification of mycobacterial DNA. Mol Microbiol 1989; 3: 843-849.

208. Peneau A, Moinard D, Beard I, Pascal O, Moisan JP. Detection of mycobacteria using the polymerase chain reaction. Eur J Clin Microbiol Infect Dis 1992: 11: 270-271.

209. Plikaytis BB, Plikaytis BD, Yakrus MA et al. Differentiation of slowly growing Mycobacterium species, including Mycobacterium paratuberculosis, by gene amplification and restriction fragment length polymorphism analysis. J Clin Microbiol 1992; 30: 1815-1822.

210. Fiss EH, Chehab FF, Brooks G. DNA Amplification and reverse dot blot hybridization for detection and identification of mycobacteria to the species level in the clinical laboratory. J Clin Microbiol 1992; 30: 1220-1224.

211. Moss MT, Green EP, Tizard ML, Malik ZP, Hermon-Taylor $\mathrm{J}$. Specific detection of Mycobacterium paratuberculosis by DNA hybridisation with a fragment of the insertion element IS900. Gut 1991; 32: 395-398.

212. Moss MT, Sanderson JD, Tizard ML et al. Polymerase chain reaction detection of Mycobacterium paratuberculosis and Mycobacterium avium subsp. silvaticum in long term cultures from Crohn's disease and control tissues. Gut 1992; 33: 1290-1213.

213. Sanderson JD, Moss MT, Tizard ML et al. Micobacterium paratuberculosis in Crohn's disease tissue. Gut 1992; 33 890-896.

214. Wu SW, Pao CC, Chan J, Yen TS. Lack of mycobacterial DNA in Crohn's disease tissue. Lancet 1991; 337: 174-175.

215. Wall S, Kunze ZM, Saboor S et al. Identification of spheroplast-like agents isolated from tissues of patients with Crohn's Disease and control tissues by polymerase chain reaction. $J$ Clin Microbiol 1993; 31: 1241-1245.

216. White S, Nassau E, Burnham, W, Stanford JL, Lennard-Jones JE. Further evidence for a mycobacterial aetiology of Crohn's disease. Gut 1978: 19: A443-A444.

217. Thayer WR, Coutu JA, Chiodini RJ, Van Kruiningen HJ, 
Merkal RS. Possible role of mycobacteria in inflammatory bowel disease. II. Mycobacterial antibodies in Crohn's disease. Dig Dis Sci 1984; 29: 1080-1085.

218. Grange JM, Gibson J, Nassau E, Kardjito T. Enzyme-linked immunosorbent assay (ELISA): a study of antibodies to Mycobacterium tuberculosis in the IgG, IgA and IgM classes in tuberculosis, sarcoidosis and Crohn's disease. Tubercle 1980; 61: 145-152.

219. Elliott PR, Lennard-Jones JE, Burnham WR, White S, Stanford JL. Further data on skin testing with mycobacterial antigens in inflammatory bowel disease. Lancet 1980; 2: 483-484.

220. Whorwell PJ, Davidson IW, Beeken WL, Wright R. Search by immunofluorescence for antigens of Rotavirus, Pseudomonas maltophilia, and Mycobacterium kansasii in Crohn's disease. Lancet 1978; 2: 697-698.

221. Haga Y, Funakoshi I, Nakajima $\mathrm{H}$ et al. Antibodies to Mycobacterium paratuberculosis in sera of patients with Crohn's disease. Dig Organ Immunol 1986; 17: 100-103.

222. Ratledge C, Stanford J. The biology of the mycobacteria: immunological and environmental aspects. New York, Academic Press. 1983.

223. Brunello F, Pera A, Martini S et al. Antibodies to Mycobacterium paratuberculosis in patients with Crohn's disease. Dig Dis Sci 1991; 36: 1741-1745.

224. Daniel TM, Debanne SM. The serodiagnosis of tuberculosis and other mycobacterial diseases by enzyme linked immunosorbent assay. Rev Respir Dis 1987; 135: $1137-1151$.

225. Thorns CJ, Morris JA. Shared epitopes between mycobacteria and other microorganisms. Res Vet Sci 1986; 41:275-276.

226. Brennan PJ. New-found glycolipid antigens of mycobacteria In: Lieve L, Schlessinger D (eds) Microbiology. Washington, DC, American Society for Microbiology. 1984: 366-375.

227. Songer JG. Environmental sources of Mycobacterium avium for infection of animals and man. Proc Annu Meeting US Animal Health Assoc 1980; 84: 528-535.

228. Camphausen RT, Jones RL, Brennan PJ. A glycolipid antigen specific to Mycobacterium paratuberculosis: structure and antigenicity. Proc Natl Acad Sci USA 1985; 3068-3072.

229. Cho SN, Brennan PJ, Yoshimura HH, Korelitz BI, Graham DY. Mycobacterial aetiology of Crohn's disease: serologic study using common mycobacterial antigens and a species-specific glycolipid antigen from Mycobacterium paratuberculosis. Gut 1986; 27: 1353-1356.

230. Camphausen RT, Jones RL, Brennan PJ. Structure and relevance of the oligosaccharide hapten of Mycobacterium avium serotype 2.J Bacteriol 1986; 168: 660-667.

231. Tanaka K, Wilks M, Coates PJ, Farthing MJ, Walker-Smith JA, Tabaqchali S. Mycobacterium paratuberculosis and Crohn's disease. Gut 1991; 32: 43-45.

232. McFadden JJ, Houdayer C. No evidence for antibodies to mycobacterial A60 antigen in Crohn's disease sera by enzyme-linked immunoabsorbent assay (ELISA). $\mathrm{J}$ Med Microbiol 1988; 25 : 295-298.

233. Kobayashi K, Brown WR, Brennan PJ, Blaser MJ. Serum antibodies to mycobacterial antigens in active Crohn's disease. Gastroenterology 1988; 94: 1404-1411.

234. Markesich DC, Sawai ET, Butel JS, Graham DY. Investigations on etiology of Crohn's disease. Humoral immune response to stress (heat shock): proteins. Dig Dis Sci 1991; 36: $454-460$.

235. McFadden JJ, Butcher PD, Winterbourne DJ, Hermon-Taylor J. No evidence for increased incidence of common cellular antigens recognized by Crohn's disease antisera. J Clin Lab Immunol 1985; 18: 87-90.

236. Perlmann $P$, Hammarstrom $S$. Antigen from colon of germfree rats and antibodies in human ulcerative colitis. Ann NY Acad Sci 1965; 124: 377-394.

237. Carlsson HE, Lagercrantz R, Perlmann P. Immunological studies in ulcerative colitis. VIII. Antibodies to colon antigen in patients with ulcerative colitis, Crohn's disease and other diseases. Scand J Gastroenterol 1977; 12: $707-714$

238. Korsmeyer SJ, Strickland RG, Wilson ID, Williams RC Serum lymphocytotoxic and lymphocytophilic antibody activity in inflammatory bowel disease. Gastroenterology 1974; 67: 578-583.

239. Brandtzaeg P, Baklien K, Fausa O, Hoel PS. Immuno- histochemical characterization of local immunoglobulin formation in ulcerative colitis. Gastroenterology $1974 ; 66$ : 1123-1136.

240. Seyrig JA, Jian R, Modigliani R. Idiopathic pancreatitis associated with inflammatory bowel disease. Dig Dis $\mathrm{Sc}$ $1989 ; 30$ : 1121-1126.

241. Niemela S, Lehtola J, Karttunen T, Lahde S. Pancreatitis in patients with chronic inflammatory bowel disease. Hepatogastroenterology 1989; 36: 165-167.

242. Kobayashi K, Blaser MJ, Brown WR. Immunohistochemical examination for mycobacteria in intestinal tissues from patients with Crohn's disease. Gastroenterology 1989; 96: 1009-1015.

243. Blaauwgeers JL, Das PK, Slob AW, Houthoff HJ. Human gut wall reactivity to monoclonal antibodies against $M$. avium glycolipid in relation to Crohn's disease (preliminary results). Acta Leprologica 1989; 7 Suppl 1: 138-140.

244. Stevens R, Oliver M, Brogan M, Heiserodt J, Targan S. Defective generation of tetanus-specific antibodyproducing B cells after in vivo immunization of Crohn's disease and ulcerative colitis patients. Gastroenterology 1985; 88: 1860-1866.

245. Morganroth J, Watson DW. Sensitivity to atypical mycobacterial antigens in patients with Crohn's disease. $A m J$ Dig Dis $1970 ; 15$ : 653-657.

246. Jiwa NM, Mulder CJJ, van den Berg FM et al. Elevated IgG to mycobacterial PPD's in Crohn's disease. In: Macdermott RP (ed) Inflammatory bowel disease, current status and future approach. Amsterdam, Excerpta Medica. 1988: 543-546.

247. Thayer WR, Fixa B, Komarkova O et al. Skin test reactivity in inflammatory bowel disease in the United States and Czechoslovakia. Am J Dig Dis 1978; 23: 337-340.

248. Beeken WL, Sessions JT, Bozymski EM. Correlations between clinical, blood leukocyte and skin test data in the National Cooperative Crohn's Diseases Study. Gastroenterology 1979; 77 : 921-924.

249. Das PK, Blaauwgeers JLG, Slob AW. On the mycobacterial aetiology of Crohn's disease: relevant immunological studies. Gastroenterology 1988; 94: A88.

250. Seldenrijk CA, Drexhage HA, Meuwissen SG, Meijer CJ. Tcellular immune reactions (in macrophage inhibition factor assay) against Mycobacterium paratuberculosis. Mycobacterium kansasii, Mycobacterium tuberculosis, Mycobacterium avium in patients with chronic inflammatory bowel disease. Gut 1990; 31: 529-535.

251. Bloom BR. Learning from leprosy: a perspective on immunology and the third world. $J$ Immunol $1986 ; 137$ : i.

252. Mehra VM, Mason LH, Fields JP, Bloom BR. Lepromin induced suppressor cells in patients with leprosy. $J$ Immunol 1979; 123: 1813.

253. Ebert EC, Bhatt BD, Liu S, Das KM. Induction of suppressor cells by Mycobacterium paratuberculosis antigen in inflammatory bowel disease. Clin Exp Immunol 1991; 83: $320-325$.

254. Kusugami K, Matsuura T, West GA, Youngman KR, Rachmilewitz D, Fiocchi C. Loss of interleukin-2-producing intestinal $\mathrm{CD} 4+\mathrm{T}$ cells in inflammatory bowel disease. Gastroenterology 1991; 101: 1594-1605

255. James SP. Remission of Crohn's disease after human immunodeficiency virus infection. Gastroenterology 1988; 95: 1667-1669.

256. Victorino RMM, Hodgson HJF. Spontaneous suppressor cell function in inflammatory bowel disease. Dig Dis Sci 1981: 26: $801-806$.

257. Auer IO, Roder A, Frohlich J. Immune status in Crohn's disease. VI. Immunoregulation evaluated by multiple, distinct T-suppressor cell assays of lymphocyte proliferation, and by enumeration of immunoregulatory $\mathrm{T}$ lymphocyte subsets. Gastroenterology 1984; 86: 1531 1543.

258. MacDermott RP, Franklin GO, Jenkins KM. Kodner IJ, Nash GS, Weinrieb IJ. Human intestinal mononuclear cells. I. Investigation of antibody-dependent, lectininduced, and spontaneous cell-mediated cytotoxic capabilities. Gastroenterology 1980; 78: 47-56.

259. MacDermott RP, Bragdon MJ, Kodner IJ, Bertovich MJ. Deficient cell-mediated cytotoxicity and hyporesponsiveness to interferon and mitogenic lectin activation by inflammatory bowel disease peripheral blood and in- 
testinal mononuclear cells. Gastroenterology 1986; 90 6-11.

260. Pirzer U, Schonhaar A. Fleischer B, Hermann E, Meyer zum Buschenfelde KH. Reactivity of infiltrating T lymphocytes with microbial antigens in Crohn's disease. Lancet $1991 ; 338$ : 1238-1239.

261. Fiocchi C, Youngman KR, Farmer RG. Immunoregulatory function of human intestinal mucosa lymphoid cells: evidence for enhanced suppressor cell activity in inflammatory bowel disease. Gut 1983; 24: 692-701.

262. Goodacre RL, Bienenstock J. Reduced suppressor cell activity in intestinal lymphocytes from patients with Crohn's disease. Gastroenterology 1982; 82: 653-658.

263. Ibbotson JP, Lowes JR, Chahal H et al. Mucosal cell-mediated immunity to mycobacterial, enterobacterial and other microbial antigens in inflammatory bowel disease. Clin Exp Immunol 1992; 87: 224-230.

264. Bartnik W. Swarbrick ET, Williams C. A study of peripheral leucocyte migration in agarose medium in inflammatory bowel disease. Gut 1974; 15: 294-300.

265. Roediger WE. A new hypothesis for the aetiology of Crohn's disease-evidence from lipid metabolism and intestinal tuberculosis. Postgrad Med J 1991; 67: 666-671.

266. Thyberg J, Graf W, Klingenstrom P. Intestinal fine structure in Crohn's disease. Lysosomal inclusions in epithelial cells and macrophages. Virchows Arch $[A] 1981$; 391 : 141-152.

267. Zurbrick BG, Follett DM, Czuprynski CJ. Cytokine regulation of the intracellular growth of Mycobacterium paratuberculosis in bovine monocytes. Infect Immun 1988; 57: 1692-1697.

268. Van Kruiningen HJ, Ruiz B, Gumprecht L. Experimental disease in young chickens induced by Mycobacterium paratuberculosis isolated from a patient with Crohn's disease. Can J Vet Res 1991; 55: 199-202.

269. Barrera LF, Skamene E, Radziocj D. Assessment of mycobacterial infection and multiplication in macrophages by polymerase chain reaction. J Immunol Methods 1993; 157: 91-99.

270. Shaffer JL, Hughes S, Linaker BD, Baker RD, Turnberg LA Controlled trial of rifampicin and ethambutol in Crohn's disease. Gut 1984; 25: 203-205.

271. Elliot PR, Burnham WR, Berghouse LM, Lennard-Jones JE, Langman MJS. Sulphadoxine-pyrimethamine therapy in Crohn's disease. Digestion 1982; 23: 132-134.

272. Rutgeerts P, Geboes K, Vantrappen G et al. Rifabutin and ethambutol do not help recurrent Crohn's disease in the neoterminal ileum. J Clin Gastroenterol 1992; 15: 24-28.

273. Picciotto A, Gesu GP, Schito GC, Testa R, Varagona G, Celle G. Antimycobacterial chemotherapy in inflammatory bowel disease. Biomed Pharmacother 1989; 43: 141-143.

274. Parker MC, Hampson SJ, Saverymuttu SH et al. Combination antimycobacterial chemotherapy with major clinical response in established Crohn's disease. Gut 198728 A1390.

275. Warren JB, Rees HC, Cox TM. Remission of Crohn's disease with tuberculosis chemotherapy. N Engl J Med 1986; 314: 182.

276. Prantera C, Argentieri R, Mangiarotti R, Levenstein S. Dapsone and remission of Crohn's disease. Lancet 1988; 1: 536 .

277. Schultz MG, Rieder HL, Hersh T, Riepe S. Remission of Crohn's disease with antimycobacterial chemotherapy. Lancet 1987; 2: 1391-1392.

278. Hampson SJ, Parker MC, Saverymuttu SH, Joseph AE, McFadden JJ, Hermon-Taylor J. Quadruple antimycobacterial chemotherapy in Crohn's disease: results at 9 months of a pilot study in 20 patients. Aliment Pharmacol Ther $1989 ; 3: 343-352$.

279. Goodman LS, Gilman A. The pharmacological basis of therapeutics. Oxford, Macmillan. 1980: 1299.

280. Prantera C, Bothamley G. Levenstein S. Mangiarotti R. Argentieri R. Crohn's disease and mycobacteria: two cases of Crohn's disease with high anti-mycobacterial antibody levels cured by dapsone therapy. Biomed Pharmacother $1989 ; 43: 295-299$.
281. Greenstein AJ, Lachman P, Sachar DB et al. Perforating and non-perforating indications for repeated operations in Crohn's disease: evidence for two clinical forms. Gut 1988; 29: 588-592.

282. Alford RH. Antimycobacterial agents. In: Mandell GL. Douglas RG, Bennett JE (eds) Principles and practice of infectious disease. New York, Churchill Livingstone. 1990: 352.

283. Yamori S, Ichiyama S, Shimokata K, Tsukamura M. Bacteriostatic and bactericidal activity of antituberculosis drugs against Mycobacterium paratuberculosis, Mycobacterium avium-Mycobacterium intracellulare complex and Mycobacterium kansasii in different growth phases. Microbiol Immunol 1992; 36: 361-368.

284. Gangadharam PRJ, Candler ER. Activity of some antileprosy compounds against Mycobacterium intracellulare in vitro. Am Rev Respir Dis 1977; 115: 705-708.

285. Van Caekenberghe D. Crohn's disease, sulfasalazine, and mycobacteria. $J$ Lab Clin Med 1989; 114: 63-65.

286. Crawford JT, Bates JH. Isolation of plasmids from mycobacteria. Infect Immun 1979; 24: 979-981.

287. Watt J, Marcus SN, Marcus AJ. The comparative effects of sulphasalazine, prednisolone and azathioprine in experimental colonic ulceration. J Pharm Pharmacol 1980; 32: 873-874.

288. Emerit J, Pelletier S, Tosoni-Verlingue D, Mollet M, Thuillier A. Essai de la superoxyde dismutase ( $\mathrm{Cu} \mathrm{Zn}$ SOD) dans le traitement de la maladie de Crohn. Chirurgie 1988; 114 : 157-162.

289. Mulder TPJ, Verspaget HW, Janssens AR, de Bruin PAF, Pena AS, Lamers CBHW. Decrease in two intestinal copper/zinc containing proteins with antioxidant function in inflammatory bowel disease. Gut 1991; 32: 1146-1150.

290. Lauritsen K. Drug treatment and formation of eicosanoids in patients with chronic inflammatory bowel disease. Dan Med Bull 1989; 36: 378-393.

291. Echevarria S, Cajigas J, Rodriguez de Lope C, Lozano JL, Romero FP. Role of prostaglandins on lymphocyte transformation in Crohn's disease. Allergol Immunopathol 1989; 17: 317-321.

292. Hawkey CJ, Karmeli F, Rachmilewitz D. Imbalance of prostacyclin and thromboxane synthesis in Crohn's disease. Gut 1983; 24: 881-885.

293. Rampton DS, Hawkey CJ. Prostaglandins and ulcerative colitis. Gut 1984; 25 : 1399-1413.

294. Peskar BM, Dreyling KW, May B, Schaarschmidt K. Goebell H. Possible mode of action of 5-aminosalicylic acid. Diy Dis Sci 1987; 32: 51S-56S.

295. Nielson OH, Ahnfelt-Ronne I, Elmgreen J. Abnormal metabolism of arachidonic acid in chronic inflammatory bowel disease: enhanced release of leucotreine $\mathrm{B}_{4}$ from activated neutrophils. Gut 1987; 28: 181-185.

296. Lobos EA, Sharon P, Stenson WF. Chemotactic activity in inflammatory bowel disease. Role of leukotriene B4. Dig Dis Sci 1984; 32: 1380-1388.

297. Emerit I, Emerit J, Levy A, Keck M. Chromosomal breakage in Crohn's disease: anticlastogenic effect of Dpenicillamine and L-cysteine. Hum Genet 1979; 50:51-57.

298. Mitchell DN, Rees RJ, Goswami KK. Transmissible agents from human sarcoid and Crohn's disease tissues. Lancet 1976; 2: 761-765.

299. Gill BS, Devriese LA, Portaels F, van den Breen L, Coussement W. Branched Mycobacterium-like organisms from swine lymph nodes. Vet Microbiol 1982; 7: 157-164.

300. Van Kruiningen HJ, Chiodini RJ, Thayer WR, Coutu JA, Merkal RS, Runnels PL. Experimental disease in infant goats induced by a mycobacterium isolated from a patient with Crohn's disease. A preliminary report. Dig Dis $S c i$ 1986: 31: 1351-1360.

301. Mutwiri GK, Butler DG, Rosendal S, Yager J. Experimental infection of severe combined immunodeficient beige mice with Mycobacterium paratuberculosis of bovine origin. Infect Immun 1992; 60: $4074-4079$.

302. Mokresh AH, Czuprynski CJ, Butler DG. A rabbit model for study of Mycobacterium paratuberculosis infection. Infect Immun 1989: 57: 3798-3807. 